\title{
THE METHOD, PROCESS AND FREQUENCY OF WEALTH TRANSMISSION AT DEATH*
}

\author{
Allison Dunham \\ I. The Problem ANd Method of INQUiry
}

7 HE laws of intestate succession are frequently asserted to be governed by the principle "that when a man dies without a will the law should try to provide so far as possible for the distribution of his estate in the manner he would most likely have given effect to himself if he had made a will."' If this is the true objective of the laws of intestate succession, then this is a unique area in which quantitative research based on experience can be useful in the legislative process. In England a committee on inquiry into the laws of succession, first in 1925, and then again in 1951,2 examined a sample of wills, in rewriting the intestate succession laws, in order to infer what persons who do not have wills would be most likely to want. ${ }^{3}$ Information gained from a study of probate court records for Cook County, Illinois, is reported and analyzed here for the purpose, among others, of determining the significance of actual practice as a basis for law reform.

Ninety-seven estates for which probate proceedings were initiated in 1953, and 73 estates for decedents who died in 1957 are the basis of this study. The years listed were chosen only because of the likelihood that estates of 1953 and 1957 would have been terminated at the time the research was undertaken in 1959-1960. The 1953 sample was obtained from a random selection of estates opened in Cook County in 1953.4 A more complicated procedure was used to obtain the 1957 sample of 73 estates. Instead of selecting this sample directly from Probate Court records, death certificates were used to obtain the sample.

* This study of the transmission of wealth at death was made under a grant to the University of Chicago Law School by the Ford Foundation. Although the responsibility for the structure of the project and of the analysis is mine I am indebted to my colleague Professor Hans Zeisel for his advice in setting up the sampling technique.

† Professor of Law, The University of Chicago.

${ }^{1}$ See, e.g., Parry, The Law of Succession 158 (2d ed. 1947); Grotius, The Rughis of WAR AND PEACE ch. 7 (1625-1646); Committee on Inquiry into the Law of Succession in Scotland, 1951, CMD. No. 8144, 8 (1957); Committee on the Laws of Intestate Succession, England, CMD. No. 8310, 3-7 (1957).

2 See Report of the Committee on the Laws of Intestate Succession, England, CMD. No. 8310 (1951).

3 Administration of Estates Act, $1925,15 \mathrm{Geo} .5, \mathrm{c} .23, \S 46$, as amended by the Intestates' Act, 1952, 15 \& 16 Geo., 6 \& 1 Eliz. 2, c. 64, §1.

4 The sample was obtained by taking the file numbers of 1953 estates in blocks of 500 , and from each block, the first 25 estates opened in that block were selected. 
After excluding all non-residents who died in Chicago and all persons who at the time of death were under age twenty, the first 500 death certificates issued in the year 1957 were selected as the basis for study. 5 The name index of the Probate Court was then read against the names on the death certificates and this procedure yielded the 73 estates that were actually investigated.

The probate records, whether selected as was the 1953 sample or the 1957 sample, have obvious limitations as a basis for investigating transmission of wealth at death. They tell nothing about capital accumulated by people whose estates are not processed at all in the court. Furthermore they give us no clue as to the amount of wealth transferred before death by people who have some capital processed through the Probate Court. Nevertheless, the state's interest in inheritance taxes, corporate rules for the transfer of shares of stock and the practices of the real estate market in requiring clear real estate titles of record are all factors that make it unlikely that many substantial accumulations escape being counted in the probate proceedings. ${ }^{6}$

\section{The Evidence as to Frequency of Probate}

\section{A. Ratio of Probate Proceedings to Adult Deaths}

The sample of 481 deaths in Chicago in 1957 comprises 1.21 per cent of the total Chicago deaths in 1957 of 39,712 persons age twenty and over. Decedents age twenty and over do not constitute the total class from whom estates may be obtained. Persons over the age of eighteen may have a will and persons at any time after birth may have capital which upon their death would be transmitted. Death certificates are not analyzed in such a way as to permit the use of the category "age eighteen and over" so "age twenty and over" was used even though some testate and intestate estates may be excluded thereby. That this is highly unlikely is shown by the fact that even in the age group twenty to twenty-nine there were no estates from the sample of 9 deaths in that category. The estates omitted by use of age twenty apparently do not represent a substantial factor. 7

5 Death certificates are so recorded in Illinois that deaths in the metropolitan area outside of the City of Chicago are recorded only in Springfield and not in the Bureau of Vital Statistics in the City of Chicago. The Cook County probate records, on the other hand, include decedents dying elsewhere in Cook County as well as Chicago.

6 It has been impossible to obtain any accurate statistics on the amount of property that is transmitted at death without probate proceedings. Statistics available in some reports on the number of joint tenancies, survivorship bank accounts and the like in comparison with interests held in individual ownership do not give us a picture either of the amount of wealth transmitted outside of probated estates or the number of decedents who have property but whose estates are not probated. Thus a person who has a joint bank account shown in statistics on joint bank accounts may also have property that must be probated. In correspondence with the author, one bank estimated that in its savings department it had two transfers pursuant to the small estate procedure, that is, estates of a value under $\$ 3,000$ for each probate transfer. In the checking accounts, however, the bank reported three probate transfers for each two small estate transfers.

7 Apparently there have been only three studies in the past that have endeavored to collect and correlate information of the type presented here. WEDGWOOD, THE ECONOMICS 
The first two columns of Table 1 compare the age distribution of decedents in the sample (column 2) with the corresponding distribution of the complete census figures (column 1). The comparison is highly reassuring as to the adequacy of the sample of 481 cases. Column 3 has the distribution of the estates in the sample by age. Columns 4 and 5 provide data relevant to distribution of estates in our sample: the corresponding distribution of estate tax returns and of life insurance policies in force at time of death. Both these columns show an age distribution highly similar to that of the estates in Chicago (column 3).

TABLE 1

DECEDENTS AND ESTATES IN THE 1957 SAMPLE By AGE, COMPARED With DEATh-CENSUS and RELEVANT U.S. Estate Data

\begin{tabular}{|c|c|c|c|c|c|c|}
\hline \multirow[b]{2}{*}{ AGE } & \multicolumn{2}{|c|}{$\begin{array}{l}\text { DECEDENTS DURENG } \\
1957 \text { (OVER TWENTY } \\
\text { YEARS OF AGE) }\end{array}$} & \multicolumn{4}{|c|}{ Estates } \\
\hline & $\begin{array}{l}\text { Census of } \\
\text { Chicago } \\
\text { (1) }\end{array}$ & $\begin{array}{c}\text { In } \\
\text { Sample } \\
(2)\end{array}$ & $\begin{array}{c}\text { Estates } \\
\text { in } \\
\text { Sample } \\
(3)\end{array}$ & $\begin{array}{l}\text { U.S. } \\
\text { Estate Tax } \\
\text { Returns } \\
\text { (4) }\end{array}$ & $\begin{array}{c}\text { Life Insurance } \\
\text { Policies at } \\
\text { Time of Death } \\
\text { (5) }\end{array}$ & $\begin{array}{c}\text { Proportion } \\
\text { in Each Age } \\
\text { Bracket } \\
\text { Having an } \\
\text { Estate } \\
(6)\end{array}$ \\
\hline $\begin{array}{l}20-29 \ldots \ldots \\
30-39 \ldots \ldots \\
40-49 \ldots \ldots \\
50-54 \ldots \ldots \\
55-59 \ldots \ldots \\
60-64 \ldots \ldots \\
65-69 \ldots \ldots \\
70-74 \ldots \ldots \\
75-79 \ldots \ldots \\
80-84 \ldots \ldots \\
85 \text { and over... }\end{array}$ & $\begin{array}{l}2 \% \\
4 \\
9 \\
7 \\
9 \\
13 \\
15 \\
15 \\
11 \\
8 \\
7\end{array}$ & $\begin{array}{l}2 \% \\
5 \\
9 \\
7 \\
10 \\
12 \\
17 \\
15 \\
10 \\
8 \\
5\end{array}$ & $\begin{array}{c}1.4 \% \\
5.5 \\
6.8 \\
13.7 \\
12.3 \\
13.7 \\
19.2 \\
15.1 \\
5.5 \\
6.8\end{array}$ & $\begin{array}{l}.1 \% \\
.9 \\
4.1 \\
5.1 \\
8.2 \\
11.3 \\
13.9 \\
14.8 \\
15.3 \\
13.2 \\
13\end{array}$ & $\begin{array}{cc}3.4 \% & \text { (under } 25) \\
2.9 & (25-34) \\
6.5 & (35-44) \\
13.9 & (45-54) \\
23.8 & (55-64) \\
27.6 & (65-74) \\
21.9 & \begin{array}{c}(75 \text { and } \\
\text { over })\end{array}\end{array}$ & $\begin{array}{l}\ddot{4} \% \\
9.1 \\
16.1 \\
20 \\
15.2 \\
12.3 \\
19.4 \\
23.4 \\
10.2 \\
\\
20.8\end{array}$ \\
\hline $\begin{array}{c}\text { Total..... } \\
\text { (Number of } \\
\text { Units)...... }\end{array}$ & $\begin{array}{c}100 \% \\
(39,712)\end{array}$ & $\begin{array}{l}100 \% \\
(481)\end{array}$ & $\begin{array}{c}100 \% \\
(73)\end{array}$ & $\begin{array}{l}100 \% \\
(35,482)\end{array}$ & $\begin{array}{l}100 \% \\
\text { (not available) }\end{array}$ & $\begin{array}{l}15.2 \% \\
(73)\end{array}$ \\
\hline
\end{tabular}

Finally, Table 1, in column 6, shows the percentage of decedents who had an estate processed in Probate Court. From zero in the lowest age brackets the percentage rises steadily until about age fifty. After age fifty the percentage

OF INHERITANCE (1929) is a British investigation which reports economic data similar to that presented here. Powell \& Looker, Decedents Estates, 30 CoLuM. L. REv. 919 (1930) collects and analyzes judicial statistical reports and inheritance tax figures over a period of time in several counties in New York. Ward \& Beuscher, The Inheritance Process in Wisconsin, 1950 WIS. L. REV. 393 is a study of the probate records of Dane County, Wisconsin, constructed and analyzed in much the same way as the 1957 sample in this report. From death certificates for $1929,1934,1939,1941$ and 1944, Ward and Beuscher constructed a sample of 415 probate proceedings for the five years examined. The author has leaned heavily on this report for comparisons. Hereafter it will be cited as The Wisconsin Study. 
fluctuates between 10 per cent in the eighty to eighty-four age bracket to 23 per cent in the seventy-five to seventy-nine age group. That persons who die between the ages of twenty and fifty should have the smallest proportion of estates should not be surprising since it is during this age interval that most people are accumulating whatever wealth they will have and at the same time are raising a family. In view of the small samples on which these percentages are based the most significant figure is the last one in the table: Only 15 per cent of all deaths are followed by estate proceedings in Probate Court.

Table 1 shows that 85 per cent of the deaths in the sample resulted in no probate proceedings. Table 2 shows substantially similar results when the

TABLE 2

Percentage of Decedents with Probate Proceedings in COOK COUNTY (1931-1957, SELECTED YEARS)

\begin{tabular}{|c|c|c|c|c|}
\hline & \multicolumn{3}{|c|}{ Percentage of Decedents with $\ldots$} & \multirow{2}{*}{$\begin{array}{c}\text { Percentage } \\
\text { Testate of } \\
\text { all Pro- } \\
\text { Ceedngs }\end{array}$} \\
\hline & $\begin{array}{c}\text { Testate } \\
\text { Proceedings }\end{array}$ & $\begin{array}{l}\text { Intestate } \\
\text { Proceedings }\end{array}$ & $\begin{array}{c}\text { Testate or } \\
\text { Intestate } \\
\text { Proceedings }\end{array}$ & \\
\hline $\begin{array}{l}1931-1935^{*} \ldots \ldots \ldots \ldots \\
1936-1940^{*} \ldots \ldots \ldots \ldots \\
1941-1945^{*} \ldots \ldots \ldots \ldots \\
1946-1950^{*} \ldots \ldots \ldots \ldots \\
1953^{* *} \ldots \ldots \ldots \ldots \ldots \ldots \\
1957^{* *} \ldots \ldots \ldots \ldots \ldots\end{array}$ & $\begin{array}{l}* * * \\
* \neq * \\
6.3 \\
7.1 \\
* * * \\
8.3\end{array}$ & $\begin{array}{l}* * * \\
* * * \\
8.5 \\
9.3 \\
* * * \\
6.9\end{array}$ & $\begin{array}{r}* * * \\
* * * \\
14.8 \\
16.4 \\
* * * \\
15.2\end{array}$ & $\begin{array}{l}44 \\
46 \\
43 \\
43 \\
60 \\
55\end{array}$ \\
\hline
\end{tabular}

total deaths in Cook County in the years 1941 to 1951 are compared with the total number of estates opened in those years. Thus it appears that a relatively small proportion of the adult population manages to accumulate any significant amount of property of a type that is customarily subjected to probate proceedings. 8

Unless the revocable trust device, the joint tenancy and other lifetime transfers and also consensual non-judicial administration have been so successful that the user of these devices dies with no assets admissible to probate, this seems to be the only possible conclusion to draw from the evidence in the tables. This conclusion will be further confirmed in later sections where the evidence on the ratio of probate proceedings to deaths is analyzed by occupation, age, sex, race and marital status.

8 The Powell study of New York, note 7 supra, reported a steady decrease between 1914 and 1929 in the percentage of deaths that resulted in no probated estates. In $1914,81 \%$ of the deaths in New York County resulted in no estates and in 1929, 72\% died without estates. The Wisconsin study showed a higher percentage of decedents with estates than either the New York study or the present Cook County study. In Dane County, Wisconsin, $42.2 \%$ of the decedents in the sample had an estate that passed through probate. The Wisconsin Study at 396. 
One further observation may be made from the evidence considered to this point. From time to time statistical studies attempt to determine the number of living persons who have wills. 9 Sometimes the reporter concludes that the resulting low percentage of wills is indicative of poor estate management or forgetfulness or of the need for renewed efforts to induce people to have wills. Since the bulk of the deaths in any one year will be deaths of persons who have no estates admitted to probate, it is hardly likely that any study of the living will show a preponderance of people with wills.

TABLE 3

PROPORTION OF DECEDENTS WITH ESTATES ACCORDING TO OCCUPATION

\begin{tabular}{|c|c|c|c|c|c|}
\hline \multirow[b]{2}{*}{ Occupatton } & \multirow{2}{*}{$\begin{array}{l}\text { NOMHAER } \\
\text { OF DECE- } \\
\text { DENTS IN } \\
\text { SAMPLE }\end{array}$} & \multicolumn{3}{|c|}{ Percentage of Decedents wite ... } & \multirow{2}{*}{$\begin{array}{c}\text { Percentage } \\
\text { of Testati } \\
\text { Estates } \\
{[1 /(1+2)]}\end{array}$} \\
\hline & & $\begin{array}{c}\text { Testate } \\
\text { Proceed- } \\
\text { ings } \\
\text { (1) }\end{array}$ & $\begin{array}{l}\text { Intestate } \\
\text { Proceed- } \\
\text { ings } \\
\text { (2) }\end{array}$ & $\begin{array}{l}\text { Either } \\
(1+2)\end{array}$ & \\
\hline 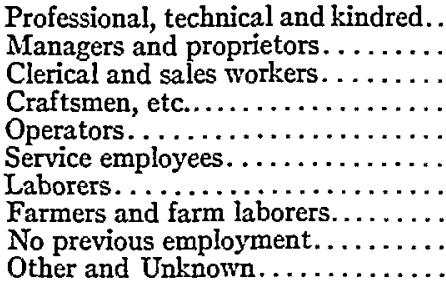 & $\begin{array}{r}(18) \\
(21) \\
(36) \\
(67) \\
(32) \\
(55) \\
(55) \\
(5) \\
(176) \\
(16)\end{array}$ & $\begin{array}{r}17 \\
47 \\
11 \\
7 \\
3 \\
3 \\
4 \\
7 \\
7 \\
13\end{array}$ & $\begin{array}{r}22 \\
5 \\
17 \\
12 \\
6 \\
9 \\
9 \cdots \cdots \\
\cdots \\
3 \\
12\end{array}$ & $\begin{array}{r}39 \\
52 \\
28 \\
19 \\
9 \\
9 \\
4 \\
10 \\
10 \\
25\end{array}$ & $\begin{array}{r}44 \\
91 \\
39 \\
37 \\
33 \\
0 \\
100 \\
70 \\
70 \\
52\end{array}$ \\
\hline Total........ & $(481)$ & 8.3 & 6.9 & 15.2 & 54.6 \\
\hline
\end{tabular}

B. Ratio of Probate Proceedings to Deaths Analyzed by Age and Occupation of Decedent

Table 3 classifies decedents according to occupation and again, as might be expected, the occupation most likely to produce accumulations produced the largest percentage of administered estates. Fifty-two per cent of the "professionals and proprietors" in the sample had estates.10

96 Powell, Real Property 606 (1958) reports on two such opinion studies. One in 1949 concluded that of the total voting age population, 3 out of 4 men and 6 out of 7 women had no wills. A study of Columbia University and teacher college graduates in 1954 indicated that the percentages of living graduates with wills varied from $28.8 \%$ for law to $69.2 \%$ for pharmacy graduates. The other schools showed $47.4 \%$ for teacher college, $51.2 \%$ for journalism and $45.7 \%$ for engineering. Carruthers, Your Will File, 98 Trust \& ESTATEs 1138 (1959) reports for a Los Angeles trust company that more than $60 \%$ of the wills withdrawn from the file result in no estate.

10 In the Wisconsin survey "professionals and proprietors" had estates in $66.2 \%$ of the deaths in the survey. The Wisconsin Study at 396. 


\section{Ratio of Probate Proceedings to Deaths Analyzed by Sex, Race and Marital} Status

Most of the women in the sample appeared in Table 3 under the category of "no previous employment." Table 4 analyzes the sample by sex and race. The totals indicate that the proportion of males who leave an estate is substantially the same as the proportion of the total population who leave an estate. White males were slightly less than 50 per cent of the population in the sample but furnished 60 per cent of the estates. Negro and White females seem to have estates in substantially the same proportion. ${ }^{11}$

TABLE 4

Frequency of Estates and Testate RATIO BY SEX AND RACE*

\begin{tabular}{|c|c|c|c|}
\hline & $\begin{array}{l}\text { Percentage } \\
\text { of Decedents } \\
\text { with Estate }\end{array}$ & $\begin{array}{l}\text { Percentage } \\
\text { Testate of } \\
\text { all Estates } \\
\text { in Group }\end{array}$ & $\begin{array}{l}\text { Number of } \\
\text { Decedents } \\
\text { in Sample }\end{array}$ \\
\hline 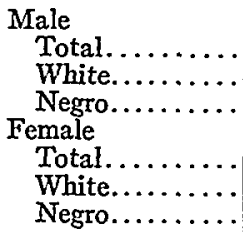 & $\begin{array}{r}17 \\
18 \\
4 \\
\\
13 \\
13 \\
13\end{array}$ & $\begin{array}{r}53 \\
55 \\
0 \\
\\
57 \\
59 \\
50\end{array}$ & $\begin{array}{r}(268) \\
(240) \\
(28) \\
\\
(213) \\
(183) \\
(30)\end{array}$ \\
\hline Total... & 15.2 & 55 & (481) \\
\hline
\end{tabular}

* 1957 only.

The marital status of the deceased at the time of death seems to be a significant factor determining the presence of an estate. The most significant marital category at time of death is "never married." One out of four of the estates in the sample came from this marital status but decedents with a surviving spouse, on the other hand, had estates in only one of nine cases. ${ }^{12}$ As Table 5 indicates, if a person has a surviving spouse at time of death or was divorced, he is less likely to have a probated estate than if he is a widow or

11 The Wisconsin Study at 396 found that $33.1 \%$ of decedent women had estates. This is substantially larger than the $13.1 \%$ shown in the Cook County survey reported in Table 4.

12 The absence of estates for persons dying survived by a spouse may indicate the prevalence of jointly held titles for assets accumulated during the marriage. A committee on jointly held titles to real property reported in 1951 that as between husband and wife, $80 \%$ of the titles to real estate in Illinois were held in joint tenancy. Similar high percentages were reported in other midwestern states. See Report of the Committee on Community Property and Joint Titles to Real Property, ABA, Section on Real Property, Probate aNd Trust LAw, 33, 37 (1952). One savings institution reported to the author that on the death of an account holder, $75 \%$ of the deceased savers had joint accounts that accounted for $80 \%$ of the total dollar value transmitted upon the death of the account holder. 
widower or a single person who has never married. The prevalence of probated estates among the "never married" category may be due not so much to an opportunity to accumulate wealth as to the inability of the distant and unrelated relatives and distributees under the will to agree on the distribution of the deceased's assets without benefit of a probate proceeding. No explanation can be obtained from the material surveyed here.

D. Conclusion as to the Relationship between Probate Proceedings and Accumulated Wealth

The frequency of estates among those over age fifty, the economically better occupations and whites who are better-off financially all support the conclusion that a very large proportion of the population does not accumulate

TABLE 5

Percentage of Decedents with Estates

ACCORDING TO THEIR MARITAL STATUS

\begin{tabular}{|c|c|c|c|c|c|}
\hline & \multirow{2}{*}{$\begin{array}{l}\text { NUMrBer of } \\
\text { DECEDENTS } \\
\text { IN SAMPLE }\end{array}$} & \multicolumn{3}{|c|}{ Percentage of Decedents with . . . } & \multirow{2}{*}{$\begin{array}{c}\text { Percentage } \\
\text { Testate } \\
\text { OF all } \\
\text { Proceedrigs }\end{array}$} \\
\hline & & $\begin{array}{c}\text { Testate } \\
\text { Proceedings }\end{array}$ & $\begin{array}{c}\text { Intestate } \\
\text { Proceedings }\end{array}$ & $\begin{array}{l}\text { Testate or } \\
\text { Intestate } \\
\text { Proceedings }\end{array}$ & \\
\hline $\begin{array}{l}\text { Spouse surviving..... } \\
\text { Widowed............ } \\
\text { Divorced. . . . . . . . } \\
\text { Never MIarried. . . . . }\end{array}$ & $\begin{array}{r}(239) \\
(152) \\
(18) \\
(72)\end{array}$ & $\begin{array}{r}6 \\
10 \\
6 \\
14\end{array}$ & $\begin{array}{r}5 \\
7 \\
6 \\
12\end{array}$ & $\begin{array}{l}11 \\
18 \\
12 \\
26\end{array}$ & $\begin{array}{l}54 \\
59 \\
50 \\
54\end{array}$ \\
\hline Total......... & $(481)$ & 8.3 & 6.9 & 15.2 & 54.6 \\
\hline
\end{tabular}

wealth sufficient to require opening an estate. Reports on the number of persons with life insurance policies, on the percentage of home ownership in the population and on the number and amount of accumulated savings in banks and other savings institutions should make us skeptical of a conclusion that finds 85 per cent of the adult population without accumulated wealth at death. 13 Unfortunately it is impossible to secure meaningful statistics on the number of decedents who had wealth that did not pass through probate. 14 The statistics on joint accounts, joint tenancies and life insurance tell us that a

13 LIFE INSURANCE FACT Book for 1957 reported that the number of persons who own some form of life insurance was estimated to be $118,000,000$ or about $70 \%$ of the population. U.S. Statistical AbSTRACT 769 (1957) estimated that about $60 \%$ of householders own their own home.

14 As a pilot project an attempt was made to analyze testate estates from the first 100 wills filed in Cook County in 1953. It was discovered that for about $50 \%$ of the testators of these wills no estate was ever opened. This "loss" in probated estates was confirmed by a similar approach to the wills filed between February 1 and 15 in 1954 and 1957 . For $42 \%$ of the testators of these wills no estate was opened. Court officials estimated that the magnitude of this loss was caused in part by extrajudicial distribution by members of the family. 
large number of people have wealth that does not pass through probate; they do not tell us that these people have no wealth that passes through probate. The most we can conclude is that a very important reason only 15 per cent of the deaths result in probated estates is the absence of wealth accumulation. If the bulk of the people have not accumulated sufficient capital to have a probated estate, and if, as will appear later, the great bulk of capital transmitted at death now passes by will, public relations campaigns to induce people to have wills will not be rewarding.

\section{Why People Have Wills}

\section{A. The Evidence as to Frequency of Wills}

These figures when compared with those in Table 2 for earlier years indicate a substantial change in the proportion of testate estates. While estimates for 195915 seem to indicate that a major trend toward testacy has developed, we should examine what the probate office classifies as an "administratorship" in the earlier years before we conclude that a change in testacy has occurred. The sample does indicate that almost 60 per cent of the estates are testate. This gross statistic tells us nothing about why people leave wills and does not in itself permit us to conclude that this is a high or low percentage. The better than 40 per cent intestate estates may not in fact involve much wealth or even persons for whom a will would have been useful or important. Further breakdown of the will statistics is necessary.

\section{B. Frequency of Wills according to Age, Occupation and Sex of Decedents with Estates}

Tables 3,4 , and 5 summarize the tendency toward wills according to a number of factors such as sex and occupation. Among factors other than wealth, age would appear to be significant in the frequency of testacies just as it was significant in determining the frequency of estates in Table 1. In the group age eighty and over, where there was a high correlation between the percentage of estates and percentage of deaths, 100 per cent of the estates were testate. The age category seventy to seventy-nine was testate in 56 per cent of the cases. Where the estates are classified by the occupation of the deceased, proprietors appear most prone to have wills. Ten of the 11 estates, or 90.9 per cent, of proprietors in 1957 were testate. Of the groups that had a substantial number of estates such as skilled workers (classified as craftsmen, operators, sales workers and clericals) the percentage of testate estates was in each case less than 40 per cent, a proportion substantially less than the proportion of testacies in the sample as a whole. 16

In Table 4, men were 53 per cent testate and women were 57 per cent testate.

1599 TRUSTS \& Estates 414 (1961).

16 The Wisconsin survey did not show that occupational differences significantly affected the use of wills; the average of all groups was approximately $47 \%$. The Wisconsin Study at 411-12. 
It would appear therefore that while the estates of men predominated in the sample, women are more likely to have a will than men.17

As Table 5 indicates, whether the decedent is a widow or widower seems to be the only marital status that substantially affects the frequency of testate estates. Decedents with that status were testate in 59 per cent of the cases. A further breakdown on the tendency toward testacy is shown in Table 6 where the proportion of testate estates is analyzed by the class of survivors.

The marital status does not seem a significant factor. The most significant factor again seems to be the fact that decedent was widowed. Women, for

TABLE 6

Percentage Testate of all Estates by Class of Survivors*

\begin{tabular}{|c|c|c|c|c|c|c|c|c|c|}
\hline \multirow{3}{*}{$\begin{array}{c}\text { SEX OF } \\
\text { DECEDENT }\end{array}$} & \multicolumn{3}{|c|}{ SPOUSE SURVTVES } & \multicolumn{5}{|c|}{ No SPOUSE SURVTVES } & \multirow{3}{*}{$\begin{array}{l}\text { GRAND } \\
\text { Total }\end{array}$} \\
\hline & \multirow[b]{2}{*}{$\begin{array}{l}\text { With } \\
\text { Chil- } \\
\text { dren }\end{array}$} & \multirow{2}{*}{$\begin{array}{l}\text { With- } \\
\text { out } \\
\text { Chil- } \\
\text { dren }\end{array}$} & \multirow[b]{2}{*}{$\begin{array}{l}\text { Total } \\
\text { Spouse }\end{array}$} & \multirow[b]{2}{*}{$\begin{array}{l}\text { Total } \\
\text { Chil- } \\
\text { dren }\end{array}$} & \multicolumn{3}{|c|}{ No Children Survive } & \multirow[b]{2}{*}{$\begin{array}{l}\text { Total } \\
\text { No } \\
\text { Spouse }\end{array}$} & \\
\hline & & & & & $\begin{array}{l}\text { Only } \\
\text { Parents }\end{array}$ & $\begin{array}{l}\text { Only Broth- } \\
\text { ers \& Sisters } \\
\text { \& their De- } \\
\text { scendants }\end{array}$ & $\begin{array}{l}\text { Total } \\
\text { No } \\
\text { Chil- } \\
\text { dren** }\end{array}$ & & \\
\hline $\begin{array}{l}\text { Male...... } \\
\text { (Total es- } \\
\text { tates in } \\
\text { group)... }\end{array}$ & $\begin{array}{r}54 \\
(37)\end{array}$ & $\begin{array}{r}50 \\
(10)\end{array}$ & $\begin{array}{r}53 \\
(47)\end{array}$ & $\begin{array}{r}61 \\
(18)\end{array}$ & (9) & $\begin{array}{r}46 \\
(24)\end{array}$ & $\begin{array}{r}43 \\
(37)\end{array}$ & $\begin{array}{r}49 \\
(55)\end{array}$ & $\begin{array}{r}51 \\
(102)\end{array}$ \\
\hline $\begin{array}{l}\text { Female.... } \\
\text { (Total es- } \\
\text { tates in } \\
\text { group)... }\end{array}$ & (7) & $\begin{array}{l}33 \\
(3)\end{array}$ & $\begin{array}{l}30 \\
(10)\end{array}$ & $\begin{array}{r}72 \\
(32)\end{array}$ & (2) & (22) & (26) & $\begin{array}{r}74 \\
(58)\end{array}$ & $\begin{array}{l}68 \\
(68)\end{array}$ \\
\hline
\end{tabular}

* 1953 and 1957 data combined.

** Includes also 6 estates where the nearest relative is more distant than parents and their descendants.

example, who were testate in only 30 per cent of the cases when survived by a spouse, became testate in almost three-fourths of the cases when no spouse survived. Although the difference was not as pronounced for men, widowed men with children were testate in three out of five cases, but in only one out of two cases if there was a surviving spouse. This suggests that a previous experience with death and its property problems in the immediate family tends to induce both men and women to have wills.

\section{Accumulated Wealth and the Use of Wills}

Tables 7 and 8 indicate the distribution of the estates among various brackets of wealth and also the significance of wealth in the frequency of testacy.

Tables 7 and 8 taken from the last complete data for Cook County in 1950

17 A survey of the Cook County records showed that in $1950,62 \%$ of the probated estates involved male decedents. The ratio of testate to total estates for men and women in 1950 is reported in Table 8, infra at p. 250. 
indicate that while the largest percentage of estates is found in the lower valuation brackets, the largest percentage of testate estates is in the higher brackets. Table 8 reveals a steady progression from less than 50 per cent testacy in estates below $\$ 10,000$ to almost 100 per cent testacy in estates over $\$ 100,000$. The sharpest increase in percentage of testacy occurs with respect to female

TABLE 7

DISTRIBUTION OF ESTATES BY VALUE OF ESTATE AND SEX OF DECEDENT*

\begin{tabular}{|c|c|c|c|}
\hline \multirow{2}{*}{ Value of Estate } & \multicolumn{3}{|c|}{ Percentage of Estates } \\
\hline & Total & Male & Female \\
\hline $\begin{array}{r}\text { Below } 5,000 \ldots \ldots \ldots \\
5,000-9,999 \ldots \ldots \\
10,000-24,999 \ldots \ldots \\
25,000-49,999 \ldots \ldots \\
50,000-99,999 . \ldots \ldots \\
100,000 \text { and over..... }\end{array}$ & $\begin{array}{r}44 \\
18 \\
22 \\
8 \\
5 \\
3\end{array}$ & $\begin{array}{r}48 \\
17 \\
20 \\
7 \\
5 \\
3\end{array}$ & $\begin{array}{r}37 \\
19 \\
27 \\
9 \\
5 \\
3\end{array}$ \\
\hline $\begin{array}{r}\text { Total ............ } \\
\text { (Number of cases).... }\end{array}$ & $\begin{array}{c}100 \\
(6683)\end{array}$ & $\begin{array}{c}100 \\
(4060)\end{array}$ & $\begin{array}{c}100 \\
(2623)\end{array}$ \\
\hline
\end{tabular}

* 1950 data.

TABLE 8

PERCENTAge Testate of ard, Estates by VaLue of ESTATE AND SEX OF DECEDENT*

\begin{tabular}{r|c|c|c}
\hline \hline \multicolumn{1}{c|}{ Value of Estate } & Male & Female & Total \\
\hline Below 5,000........ & 22 & 31 & 25 \\
$5,000-9,999 \ldots \ldots$. & 51 & 61 & 56 \\
$10,000-24,999 \ldots \ldots$ & 60 & 67 & 63 \\
$25,000-49,999 \ldots \ldots$ & 78 & 80 & 79 \\
$50,000-99,999 . \ldots \ldots$ & 85 & 89 & 86 \\
100,000 and over..... & 98 & 94 & 96 \\
\hline Total.......... & 44 & 56 & 49 \\
\hline
\end{tabular}

* 1950 data.

decedents, and it is not until the largest category of estates is reached that the percentage of male testacy exceeds that of the female. In the sample years a similar result is reached as to estates subject to estate taxes; 100 per cent of this type of estate is testate if the decedent is male but only 75 per cent if the decedent is female. From the estates in the sample years 1953 and 1957 as to which sufficient information was available to obtain a total of the values stated for probate, it would appear that 90 per cent of the wealth transmitted at death through probate was transmitted in testate estates. 
$\$ 4,031,458$ was transmitted by will as against $\$ 441,680$ by intestacy. 18 This conclusion, that the bulk of the wealth is transmitted by will even though only about 60 per cent of the estates are testate, is significant in evaluating the public relations efforts of the legal profession and corporate executors attempting to induce people to leave wills. While the ideal may be that 100 per cent of the wealth transmitted at death should be transmitted by will, nevertheless, if about 90 per cent of the wealth is now transmitted by will, it is questionable whether any substantial "return" would accrue from intensifying efforts to induce people to plan their estates. At least if an objective of the public relations campaign is to aid the economic status of the Bar, it is questionable whether an important increase in legal business would result from having 100 per cent of the decedents die with wills. Of course there may be important by-products to a campaign concerning wills and estate planning insofar as this attracts to the corporate trustee or lawyer persons who have business other than will drafting.

Capital accumulation therefore appears to be a major factor in a decision to have a will rather than to die intestate. This could mean, however, only that those who accumulate substantial capital have, through orderly arrangement of their affairs during life, acquired "know-how" about transmission of wealth at death. Capital accumulation, however, is not alone a sufficient explanation for a will. Wealth could be distributed through the intestate laws just as easily as through the form of a will. It is possible to have a will that disposes of property in accordance with the intestate succession laws. Some insight as to why people have wills may therefore be obtained from considering the degree of conformity or non-conformity of their wills to the intestate succession laws.

\section{Tendency in Wills to Depart from the Distribution Rules of the Intestacy Statute}

The English studies referred to in the introductory section indicated that two parliamentary commissions have thought that representative wills would show how people wanted their property to be distributed at death. Table 9 shows an analysis of the wills in the sample in terms of the number and percentage that deviate from the existing intestacy rules.

If we omit distant relatives, deviation appears to occur most often where the deceased is survived by a spouse and children and least often where the deceased is survived by a spouse but no children. In both of these situations the percentage of testate estates is less than the percentage for the whole (column 1). The second largest group deviating from the intestacy laws is also a group where the percentage of testate estates is below the percentage for the whole. 19

18 Stephenson, Trust Business in Hawaii, 100 TRUSTS \& EsTATES 73 (1961) reports that in Hawaii in 1949 it was estimated that $85 \%$ of the total property transmitted at death passed under a will.

19 See Table 9 infra p. 252. 
If we look at these figures alone we seem to have two conflicting tendencies: If we assume that one purpose of having a will is to deviate from the intestacy laws, then there is less tendency to deviate from intestacy laws when the deceased is survived by a spouse than when other survivors are involved. If we assume that the distribution patterns expressed in the will indicate what the common expectation on death is, then the expectation of society appears to deviate sharply from the intestate laws where there is a spouse and where there are only brothers and sisters. An analysis of the patterns of distribution in the wills may help explain this apparent inconsistency.

Under the Illinois intestacy laws the share of the spouse varies with the existence of descendants. If there are descendants of the deceased, the surviv-

TABLE 9

DEVIATION FROM INTESTATE SUCCESSION BY TESTATION

\begin{tabular}{|c|c|c|c|}
\hline Survivor & $\begin{array}{c}\text { Percentage } \\
\text { Testate of } \\
\text { all Estates } \\
\text { (1) }\end{array}$ & $\begin{array}{l}\text { Percentage of } \\
\text { all Testate } \\
\text { that Deviate } \\
\text { from Intes- } \\
\text { tate Rule } \\
\text { (2) }\end{array}$ & $\begin{array}{l}\text { Percentage of } \\
\text { all Estates } \\
\text { that Deviate } \\
\text { from Intes- } \\
\text { tate Rule } \\
(1 \times 2) \\
\text { (3) }\end{array}$ \\
\hline $\begin{array}{l}\text { Spouse and children........ } \\
\text { Spouse without children.... } \\
\text { Children without spouse.... } \\
\text { Neither spouse nor children } \\
\text { but brothers or sisters.... } \\
\text { Other relatives survive..... }\end{array}$ & $\begin{array}{l}50 \\
46 \\
69 \\
\\
54 \\
67^{20}\end{array}$ & $\begin{array}{r}100 \\
17 \\
69 \\
89 \\
100\end{array}$ & $\begin{array}{r}50 \\
8 \\
47 \\
\\
48 \\
67\end{array}$ \\
\hline
\end{tabular}

ing spouse receives only one-third of the estate and the children the remaining two-thirds. If there are no descendants, the surviving spouse is entitled to all of the personal estate and one-half of the real estate. Table 6 indicates that males were more often testate if survived by spouse than were females. An examination of the 22 testate estates where the deceased was survived by spouse and children shows that 100 per cent left all of the property to the surviving spouse contrary to the intestacy laws. 21 In the 6 testate estates where

20 When the remaining 8 wills are considered, most of which involved parents, the percentage of deviation becomes 76.6 , i.e., less than $25 \%$ of the wills conform to the intestate laws. The Wisconsin survey concluded that about $20 \%$ of the wills were identical or "almost identical" with the intestate laws. It found that in only $37.4 \%$ of the cases was one or more heirs omitted but only $40 \%$ of these cases could be accounted for by the wills that gave a larger share to the spouse. The Wisconsin Study at 413 . The Cook County survey found $31 \%$ of the deviations caused by gifts to surviving spouse but only $28.5 \%$ of the wills involved situations where there were surviving spouses. Table 10 infra p. 265.

21 There are indications in the Illinois statutes that the probate act formula does not conform to modern expectations. There are many statutes providing for pensions, death benefits and the like for government employees such as legislators, judges, firemen and school teachers. For a description of the statutes see, Dunham, Sixty Different Succession Laws in Illinois, 46 IrI. B.J. 741 (1958). Oddly enough, these laws conform to the intestate laws in 
there was a surviving spouse but no children all but 1 gave the surviving spouse all of the property in conformity with the intestacy law for personal property. The 1 estate in this category involved a female testator. As Table 6 indicates females are less often testate than men when the survivors include a spouse. Since the male is usually an accumulator of wealth in his own right, the conclusion that we might draw is that the presence of other sources of income in the surviving spouse weakens the expectation that the survivor takes all. In any event the pattern of distribution in wills favoring the surviving spouse is clear: 27 of the 28 wills left all to the surviving spouse. 22

Where a deceased is survived by children and descendants of children but no spouse, the intestate succession laws provide for equality of distribution among the stirps, that is, each living child takes a share and the children of a deceased child as a group take the share of their ancestor. If equality of distribution is what society expects among children, then we might expect fewer wills where a deceased is survived only by children than in other categories. As Table 9 indicates, the percentage of intestacy does not support this conclusion. It is true, however, that in the total estates there is less deviation in this category. But the wills themselves tend to deviate from the in-

$24 \%$ of the cases, about the same percentage as the wills in the study conformed to the intestate law. See note 17 supra. In the bulk of these laws, the employee's contributions to a retirement plan are refunded, if he dies before retirement, to the surviving spouse. For an indication of an added "cost" of the probate act formula see note 22 infra. In LIFE INSURANCE FACT Book for 1957, it appears that death claims on all insurance policies during September 1955 were paid to the wife in $40 \%$ of the policies on which claims were paid. It also appears that $60 \%$ of the total payments were made to the wife. The percentages are larger on ordinary life and group policies. For group policies, $65 \%$ of the policies on which death claims were paid were payable to the wife and this constituted $74 \%$ of the amount paid. For ordinary life policies, the percentages were $59 \%$ and $65 \%$.

22 The United States Civil Service Commission reached a similar conclusion after comparing the number of beneficiary designations on file under the civil service retirement scheme with those on file under the Railroad Retirement Act. Under the Railroad Retirement Act where there were 7,900,000 eligible employees only 21,000 had designated a beneficiary of the sums due in case of death before retirement. The Railroad Retirement Act provided that the sums on deposit, if an employee dies before retirement, were to be distributed in accordance with a priority stated in the act itself: First, to the wife; if none, to the children, and so on until the last alternative, the intestate laws of the state of residence of the employee. In each case the employee was free to designate a beneficiary.

More than $90 \%$ of the civil service employees, over $5,000,000$, had designated a beneficiary, usually the wife. The statute for civil service employees provided that absent a designation of beneficiary, distribution would be made in accordance with the intestate succession laws.

The Commission concluded that the major reason for the difference in percentage of beneficiary designations was dissatisfaction with the local law of intestate succession. It recommended to Congress that the railroad retirement scheme of distributing all to the wife absent a designation be adopted in order to have a scheme that accorded with the expectation of employees and in order to save the expense of warehousing the large number of beneficiary designations. See H.R. REP. No. 2163, 81st Cong., 2d Sess. (1950).

After this change in the law, the number of beneficiary designations fell to less than 125,000 according to a letter from the Commission. 
testate succession laws. In the 1957 sample, when the deceased was survived by children alone, 6 of the 8 wills, or 75 per cent, avoided the equality of distribution prescribed by the intestate succession laws. In 1953, 18 of the 27 estates, or 66.6 per cent, avoided the equality principle of the intestate succession laws. While there is no clear pattern as to the form which this variance takes, the modal form is that of varying the shares of the children so that they do not share equally rather than giving property to persons other than the children. The second most common variation from the intestate succession laws is that of including others, such as grandchildren and wives of children, who would not take under the intestate succession laws.

The intestate succession laws also provide for equality of distribution among the brothers and sisters of a deceased who is not survived by a spouse or by children and their descendants. 23 As Table 9 indicates, here the preference for wills over intestacy is not very substantial. However, 89 per cent of the wills, where there were surviving brothers and sisters, avoided the equality of distribution of the intestate succession laws.

A further function of the will in this situation can be shown by an analysis of wills in which gifts to charities occur. In the sample, 10 of the 15 charitable gifts appeared in estates in which brothers and sisters were the closest relatives of the deceased. 24

We now can draw some conclusions about deviations from the intestate succession laws. It would appear that in situations where a spouse is not involved, the deviations represent individual preferences of the testator depending on such a wide range of variables that no pattern capable of reduction to statute can be found. For example, where the deceased was survived by children but no spouse, deviations from the principle of equality embodied in the statute reflect desires that cannot be standardized into statutory language. Since some 'rule is needed, the equality of distribution among descendants now provided by statute may be viewed not so much as a desirable rule as one which is neutral on the complicated relationships between an owner and his descendants and their families. When descendants are involved, the key questions of legislative reform would seem to be two: (1) Should an ancestor be permitted as much freedom as he now has for varying shares of his descendants including the freedom to disinherit; and (2) should a judge or some public agency be substituted for the testator, where the testator does not adequately consider the differing claims of his descendants and provides for equality where society would deviate from equality?

When a surviving spouse is involved, the wills analyzed indicate much more of a pattern of expectations as to an appropriate share for the surviving

${ }^{23}$ See Table 6 supra p. 249.

24 WEDGWOOD, op. cit. supra note 7, reports that in England in estates over $£ 50,000$, $65.2 \%$ left nothing to charity and in five-sixths of the estates the bequest was less than $5 \%$ of the property. 
spouse. This pattern, capable of being reduced to statutory language, deviates sharply from the distribution provided by the intestate laws. In a subsequent section we will consider whether the study warrants a conclusion that the intestate laws should be changed.25

In the estates in which the survivor is more distant than brothers and sisters and their descendants, none of the estates conformed to the statute of distribution and almost all permitted strangers and others to take a substantial portion of the estate.

\section{E. Disinheritance of Children}

Before considering the implications of the analysis of wills for law reform, we should determine, if possible, the consequences of freedom of testation for distributions within the family. Anglo-American commentators and visitors from civil law countries frequently note with a certain amount of horror the possibility, under our law, that a person might disinherit his own children. ${ }^{26}$ The civil law system provides for a legitime for the children which cannot be taken away by a will or lifetime gift.27 It is frequently proposed that the AngloAmerican system should introduce a non-barrable statutory share for the descendants in the same way that our present system has such a share for the surviving spouse. The above material indicates that there is no need in practice for a non-barrable share for the surviving spouse; the surviving spouse is given much more than the statutory one-third in a very high percentage of the wills. 28 By reason of this same fact, however, a substantial percentage of the testate estates "disinherit" the children and in the cases where there is no surviving spouse but surviving children the above analysis indicates that in a number of estates the share of the children is not calculated according to the principle of equality. Yet other research seems to indicate that there is a rather

25 See p. 257 infra.

${ }^{26}$ See, e.g., Cahn, Restraints on Disinheritance, 85 U. PA. L. REv. 139 (1936); Laube, The Right of a Testator to Pauperize His Helpless Dependents, 13 CORNELL L.Q. 559 (1928); McMurray, Modern Limitations on Liberty of Testation, in RATIONAL BASIS OF LEGAL INSTITUTIONS 452 (1923). This possibility was a moving cause of the WEDGWOOD study, op. cit. supra note 7.

See also Gold, Robson, Kahn-Freund \& Greslaver, Freedom of Testation, 1 MoD. L. REv. 296 (1938).

27 See Dainow, Forced Hiership in French Law, 2 LA. L. Rev. 669 (1940).

28 But see, MacDonald, Fraud on the Widow's Share (1960) who reports an accelerating increase in litigation involving a share for the spouse. His statistics, based on reported cases, show a fourfold increase in such litigation since 1900 with only a twofold increase in population. Id. at 7. He does not compare the increase in litigation of this type with the increase in testacy or estates in the same period nor with the increase in estates generally. His statistics show 17 cases for the decade ending in 1929 and 68 cases for the eight year period ending in 1958. If we assume they all arose in Cook County the increase is actually less than double for if the total wills in Cook County are taken as the base, the rate of such litigation increased from 6 per 10,000 wills to 10 per 10,000 wills. This would not appear alarming. 
strong feeling that parents should not be permitted to disinherit any of their descendants. 29

If these attitude studies are taken as a true reflection of society's attitude about disinheritance, then refinement of the meaning of the term "disinheritance" appears to be necessary before we may discuss the desirability of a system similar to the European legitime. The fact that 100 per cent of the wills where there is a surviving spouse and children produced a technical disinheritance of the children by leaving all to the wife must mean that most testators do not regard this method of distribution to be a "disinheritance." If this conclusion is correct, it follows that the true meaning of disinheritance in the minds of people using the term is that which results only on the final distribution from one generation to the next, that is, when the surviving spouse distributes and excludes children or includes persons other than children. In the sample of 24 testate estates in which there were surviving children but no surviving spouse, ${ }^{30} 17$ of the wills provided for a distribution that deviated from the intestate laws, but in only 2 cases was a child excluded, and even then only to include his descendants. An analysis of the estates in the two years that deviated from the intestate succession laws would seem to indicate that there is no basic pattern of deviation. The modal form of deviation seems to be that of including all of the children but deviating from the principle of equality. The second most common pattern in the deviation is that of excluding grandchildren, that is, descendants of a deceased child. In 2 cases there was a gift to an outsider, in both cases a gift to a divorced wife, and in one case there was a gift to say Masses. In short, the samples indicate that disinheritance even in the sense of distributions from the last survivor of the parents is not a major problem. However, there are unequal distributions reflecting individual differences which do not lend themselves to legislative standardization.

Another approach to the problem of disinheritance is to consider the age or probable ages of the children who might be disinherited under the wills. From commentators and writers on the question of disinheritance of children, it would appear that the standard image of the writer is that of disinheritance of a minor child at a time when the child needs continuation of the parent's support for several remaining years. Statements in the American and English

29 Cohen, Robson \& Bates, Parental Authority: The Communtty and the LAW (1958) report answers to a questionnaire on the propriety of allowing parents to disinherit children. The question posed only the situation where the surviving parent disinherits the children. The results reported showed that $93.4 \%$ of the respondents would prevent disinheritance if the child was under 21 but only $63.4 \%$ would prevent it if the child was over 21. An even lesser percentage (57.3\%) would prevent disinheritance if the surviving child was well-off financially. 78.5\% disapproved of discrimination among the children. This study was conducted in Nebraska.

30 Both The Wisconsin Study and the Cook County study seem to indicate that persons who definitely make decisions (i.e., leave wills) have a different attitude toward inequality of distribution than those sampled in the attitude study reported in note 27 supra. Whether the difference is a geographical difference or a difference from the actualities of decision making cannot be determined. 
literature concerning disinheritance of children appear all to derive from similar statements made at the time of the adoption of the legitime principle on the Continent, that is, they derive from a time when the life expectancy of the average parent was much shorter than it is today so that it was likely that a parent would die with minor children surviving him. The 1953 sample was analyzed to determine how often, when there are surviving children and descendants of surviving children, a guardian ad litem must be appointed in the probate proceedings to represent the interests of the minor heirs or takers under the will. In the 56 estates, both testate and intestate, in 1953 in which this information was available and the deceased had surviving descendants, only 12 , or 21.4 per cent, required the appointment of a guardian to represent the minor heirs. ${ }^{31}$ In only 2 of the 56 estates was representation of minor children required; all other cases of guardians ad litem involved minor grandchildren of the deceased, where a son or daughter had predeceased the decedent. In short, in the 1953 sample in only 3.5 per cent of the cases was the deceased parent's death at a time when his children were minors. The 1957 sample of 33 estates with surviving descendants was analyzed in terms of the age of the deceased at the time of his death. The median age for both intestate and testate male decedents with surviving descendants was 65 . For females the intestate median age was 69 and the testate median age was 80 . While it is possible that decedents at this median age, at least in the case of males, could have minor children, it is quite unlikely. In the 1957 sample only one-fifth of the decedents with surviving descendants died under the age of sixty. To the extent that commentators on the question of disinheritance are disturbed at the thought of a deceased parent disinheriting his minor children, the conclusions from the samples would seem to indicate that the problem is one that does not really exist in modern society given the longevity of the average adult together with the early marriage and the early time of having children. The child who might be disinherited is much more likely to be a child with a grown family of his own than a minor child. 32 This is further borne out by the previous analysis of the estates in which the deceased was survived by children but no spouse. In 50 per cent of the cases where there was deviation from the principle of equality, the deviation is explained by the existence of grandchildren and the decease of adult children.

\section{Reform of Statute of Distribution}

Illinois has not been noted for reform of its statutes concerning distribution of wealth at death. The United States Congress in the Northwest Ordinance of 1787 gave the Illinois territory a formula for distribution of wealth at death,

31 The Wisconsin Study at 423 indicated that the appointment of a guardian was necessary in $15.9 \%$ of all the estates in the sample. It did not break this figure down in order to distinguish children from grandchildren.

32 WEDGWOOD, THE ECONOMICS OF INHERTIANCE 190 (1929) reports from his study of the English estates in 1926-1928 that the average age of children who survive well-to-do parents is about 40 . 
modeled after the English Statute of Distribution of 1670 for personal property. Since 1787 there have been only two major changes, both concerning the share of the surviving spouse. The Northwest Ordinance provided that on intestacy the surviving spouse was to receive one-third of the personal property absolutely. About sixty years later, in 1845, the surviving spouse was given all of the personal property in situations where the deceased owner died survived by no descendants. There have been no further changes in the share of the surviving spouse in personal property. In 1787 the surviving spouse had only a dower or curtesy interest in land, that is, a life interest only in certain kinds of real estate. This formula of a life interest only in land continues to this date, although in 1845 where there were no descendants, and in 1923 where there were descendants, this life interest became optional. On the dates mentioned the surviving spouse was given an absolute share in a portion of the land if the spouse did not elect to take dower or curtesy. In 1845, if the owner died with no next of kin, the surviving spouse was given an absolute interest in one-half of the land and finally in 1871 was given all of the land just as the spouse was given all the personal property in that situation. In 1845, if there were next of kin but they were more distant than parents or descendants of parents of the deceased, the surviving spouse was given an absolute interest in one-half of the land and finally in 1929 given all of the land in the same manner as personal property. Where there were parents or descendants of parents but no descendants of the decedent, the surviving spouse was given one-half of the land in 1845 at the same time that the spouse was given all of the personal property. This formula continues to this date. In 1923, land and personal property rules were assimilated in the sense that thereafter, even if the deceased were survived by descendants, the surviving spouse was given one-third of both land and personal property. Chart 1 shows graphically the times at which various changes have occurred. The years mentioned were the years in which there were changes enacted by the General Assembly.

With respect to other claimants the Illinois Statute of Distribution has adhered to the principle of equality of distribution since the beginning of territorial law, and it continues to adhere to this principle. The only changes that have been made in the shares of persons other than a surviving spouse have been the reduction of the share when the wife's share was increased and, in 1959 , the adoption of a parentelic system to determine the takers through great-grandparents and their descendants. 33

We may now consider the implications of the analysis of wills for legislative reform of the laws concerning transmission of wealth at death. The most obvious conclusion is that the present statutory share of one-third of the estate for the surviving spouse, if there are children, is almost completely contrary to the expectations of the average testator. Both English surveys reached the same conclusion and the Illinois statutes concerning pensions for specialized

33 Ill. Rev. STAT, ch. 3, § 11 (1961). 
employees are also in accord. ${ }^{34} \mathrm{~A}$ need for reform of the distribution statute as to the spouse's share seems obvious unless one is able to substantiate alternative conclusions: The intestate laws should deliberately deviate from normal expectations in order to induce people to make wills; or the expectation of the class of persons who make wills is not the same as the class of persons who do

34 ILL. REV. STAT. ch. 127, § 222 (1961).

\section{CHART 1}

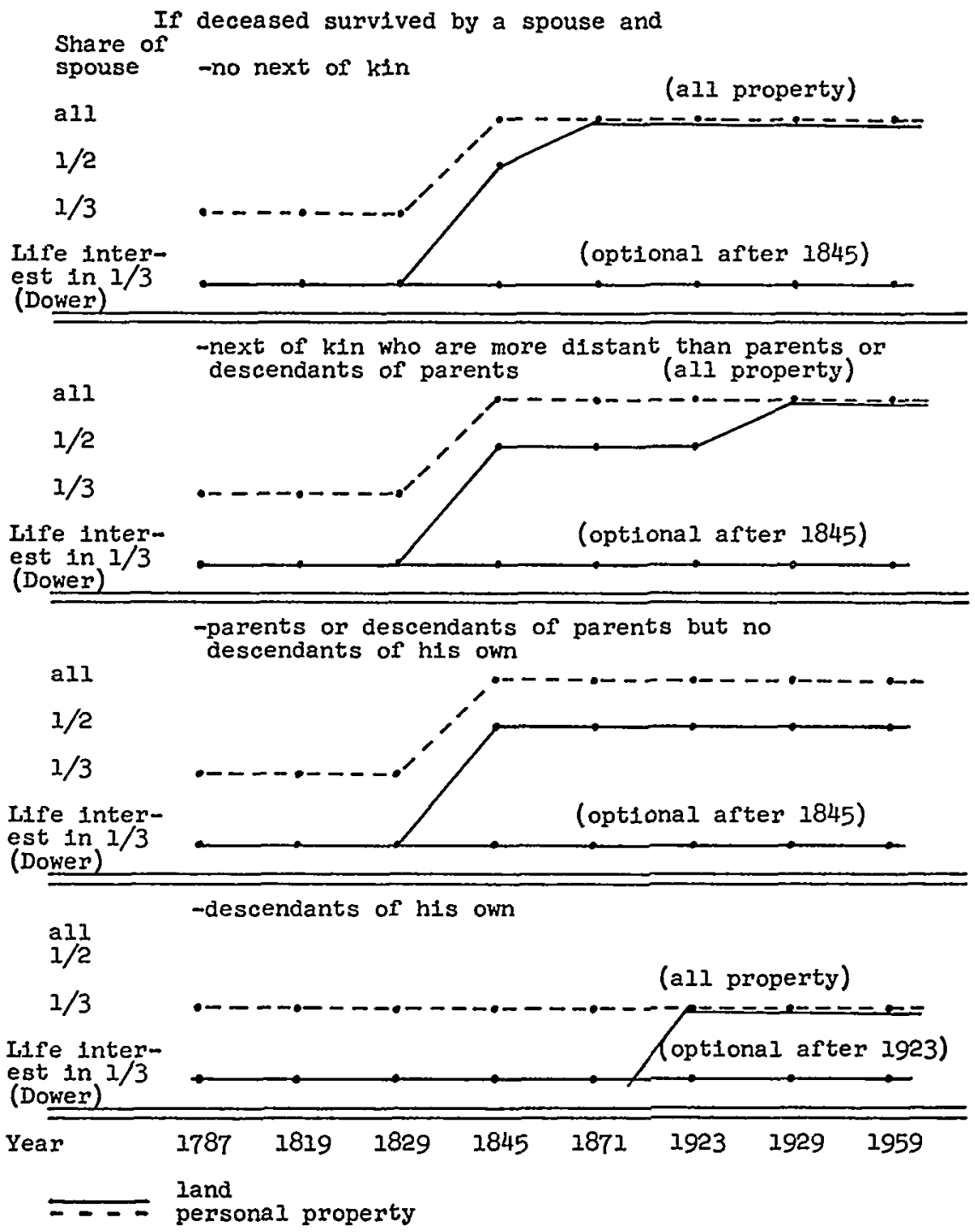


not make wills and the intestacy laws are for this latter group of persons. The first alternative is a position that quantitative research cannot determine but the second is capable of proof or disproof. For example, a study could be conducted in which persons are asked to choose a preferred method of distribution when the deceased is survived by a spouse and children. The respondents could be asked to rank in order of preference a scheme that gives all to the surviving spouse; one that gives the spouse one-half; one that gives the spouse the present statutory share of one-third; and one that gives the spouse the income from all of the accumulated capital for life but none of the principal. To determine the preferences when various variables are introduced, the respondents could be asked to rank the same schemes when other factors are present. For example, in tentatively using such a questionnaire, we posed a situation in which the husband and father was age thirty-five with three small daughters and one in which he was age fifty-five with three married daughters with families of their own. Two other variants were introduced in this survey: the amount of the accumulated capital was small in one case and large in the other; in one case the surviving spouse had an income independent of the other spouse and in the other no means of support other than that given to the surviving spouse by the first to die. Other variables could, of course, be introduced.

In the small use of such a questionnaire which we made, the present statutory scheme was chosen as a first choice in only 4 per cent of the answers and was a second choice in only 20 per cent of the answers. Fifty-four per cent of first choices and 11 per cent of the second choices gave all to the surviving spouse.

Both the size of the estate and the age of the surviving children were significant variants. If the estate was small $(\$ 36,000)$ a distribution that gave all to the surviving spouse was preferred in 85 per cent of the answers and was second choice in 11 per cent of the answers. A distribution of one-half to the spouse was first choice in a few answers where the spouse had other income and second choice in 75.7 per cent of the answers. The present statutory share was preferred in 2.5 per cent of the answers and was second choice in none.

If the estate was large $(\$ 180,000)$ the distribution of all to the surviving spouse was no longer the preferred plan. It received only one-fourth of the first choices and 10 per cent of second choices. The first preference of 40 per cent was a distribution of one-half to the wife and this method was second choice in 48 per cent of the answers. Thirty per cent of those answering preferred a distribution that gave the spouse all of the income but none of the principal. The present statutory scheme was last on the list of first choices ( 5 per cent) but was the second choice in 34.2 per cent of the answers.

The age of the surviving children was also of some importance in determining the desired pattern of distribution but it was not as important as accumulated wealth. If the surviving children were young, a gift of all to the 
spouse was a first choice in 47.5 per cent of the replies as against 60 per cent of the replies if the survivors had already established their own families. If the children were young, 60 per cent favored as a second choice a distribution of one-half to the spouse; if the children were adults, 62.8 per cent favored this as second choice. Again the statutory scheme was low on the list of preferences.

Aside from the almost uniform rejection of the present statutory scheme, the most significant result of this pilot survey is the evident weakening of the claim of the children as against the wife if the children are adults. While all of the respondents gave all to the surviving spouse if the estate was small and the spouse had no other income, less than one-half of the respondents gave all to the surviving spouse if the estate was large. But, if the children were adults, 25 per cent gave all to the spouse as against 20 per cent if the children were minors. If the surviving spouse had other income, however, the claim of the spouse as against the children was reduced if the children were adults but remained the same if the children were minors.

For law reform the substantive results of this questionnaire would seem to be this, if a larger sample would support the present conclusions: Up to some amount of accumulated wealth between $\$ 36,000$ and $\$ 180,000$ a statutory scheme giving all to the wife would accord with most expectations even if variables such as the independent income of the spouse and the age of the surviving children were ignored. Beyond this at present unknown figure, the other variables such as the independence of the spouse and the age of the children become too significant to ignore.

For law reform the questionnaire presents a problem that is not substantive: Should the statute continue to leave all to the wife in excess of the mythical figure referred to above (as did all of the wills analyzed) with the hope that the accumulating spouse who has different expectations for a larger estate by reason of the variables would provide for them by will? Or should the statute attempt to provide for as many variables as possible? Or should the draftsman pick some arbitrary sum as a compromise that he believes does least damage to the expectations and allows for precise consideration of the variables by the will of those inclined to have a will? Empirical research does not appear very helpful in resolving this procedural problem. Other considerations are also presented.

If our new statutory scheme gives all of the intestate estate to the surviving spouse, then with the existing Anglo-American freedom of testation, the spouse who accumulated the capital but failed to make a will must rely completely on the surviving spouse to leave all of the property to the descendants either by will or by dying intestate if survived by descendants. The wills analyzed indicate that this is what occurs in the great bulk of estates even without compulsion, that is, the testate surviving spouse leaves all of the property to the descendants or at least the surviving descendants. If we follow through completely on the idea that the intestate succession laws are to mirror what 
people who make wills normally do, then the law should provide that all of the intestate assets go to the surviving spouse and on the death of that spouse all of the assets should be distributed to the descendants. But, all that the study really indicates quantitatively is that most people are "good" people and seldom really disinherit their spouses or children; the study does not establish that there are no people who would disinherit the spouse or the children. The real question therefore is whether there is need for a provision at some point in the distribution system restricting freedom of testation in order to reduce or prevent the harm that the occasional "bad" man might cause. One method of reducing this possible harm from a "bad" testator is the existing method of a non-barrable share for the spouse which leaves some of the property to the surviving spouse but gives the balance directly to the descendants of the accumulating spouse free of control of the surviving spouse. While a system that provides for automatic distribution to both the spouse and the descendants reduces the chance of the surviving spouse's deviating in a shocking way from the desires of the accumulating spouse, it does so at a price-the risk that the surviving spouse, if given less than all, is unable to maintain herself economically on the share given to her. Thus in an estate of $\$ 36,000$ the existing system gives the spouse only $\$ 12,000$ of the accumulation and gives the children $\$ 24,000$. It is obvious that the surviving spouse, even if she could support herself on the $\$ 36,000$, is unable to maintain that support on the $\$ 12,000$ given to her. This suggests that a compromise may be in order and the English surveys previously referred to effected such a compromise. The English statutory procedure is a compromise in two ways: It gives the surviving spouse all of the estate if it is below a certain capital value, but as to larger estates, 35 it limits the surviving spouse to the income from the capital. This seems to be on the theory that for small estates there is no way in which the expectations of the accumulating spouse as to transmission of wealth to his descendants can be protected without at the same time making it almost impossible for the surviving spouse to support herself; therefore when a choice must be made we should protect the surviving spouse, usually a "good" spouse, at the risk that the occasional "bad" spouse would disinherit the children. The study does not suggest a figure at which decedents with wills tend to give less than all to the surviving spouse. Economically it would seem clear that for estates not subject to federal estate tax because of the smallness of the gross estate all should probably be left to the surviving spouse. This would mean an intestate system that gave the first, let us say, $\$ 50,000$ to the surviving spouse and thereafter only some proportion, such as one-half of the intestate estate should be left to the surviving spouse.

When we consider the situation of a decedent survived by children but no

35 It is stated that since $87 \%$ of the estates in England are less than the $£ 5,000$ given the spouse, the effect is to give the spouse all of the estate. Mitchell, Report of the Committee on Intestate Succession, 14 MOD. L. REV. 478 (1951). 
spouse we are again presented with the same problem: Should there be a provision for a non-barrable share for children of the "bad" testator even though we know that in the bulk of the wills in such a situation the testator leaves all of his property to his children? Here the price paid for a non-barrable share is that of forbidding a parent to vary the shares of his children by reason of unusual circumstances such as an invalid child, or to exclude a missing child, an unworthy child, or grandchildren who are adequately provided for through other channels. As the analysis of wills indicates, these factors seem to be the standard reasons for deviating from the principle of equality among descendants. If legislation providing for a non-barrable share for descendants cannot be made discriminating enough to allow for flexibility by testators, then the "cost" of compelling a gift by a "bad" decedent may make the legislation not worth the price of the restrictions imposed on the "good" testator. It is significant that in this area other parts of the Anglo-American system of freedom of testation have deviated from the freedom, not by providing a non-barrable share in a fixed amount, but by allowing the judge to rewrite the will or intestate laws. ${ }^{36}$

Thus a further implication for law reform from the research undertaken is to sharpen the issue that must be decided in determining the formula for shares: The statute is not so much to mirror the expectations of the "good" testator expressed in the sample wills as it is to reduce the harm that "bad" spouses can impose on the other spouse or the descendants. ${ }^{37}$ Quantitative research clarifies the issue but it does not answer it.

A final question that emerges from this study concerns the statutory treatment of relatives more distant than brothers and sisters. When there is no will, is there any justification for preferring these more distant relatives to the state or county by an escheat? It would appear here that decedents in this category are likely to have a will when they want to provide for deserving friends and charities, and in other cases they simply do not care what happens to their property.

\section{A. Size of Estates}

\section{The Estate}

The study indicates that few persons die owning an accumulation of any sizable fortune. Taking the two years 1953 and 1957 together, 42.7 per cent of the estates that passed through the Probate Court had a stated value of less than

36 See the extended discussion of the British Commonwealth Family Maintenance legislation in MACDONALD, op. cit. supra note 26, at 290-98, and the bibliography at $291 \mathrm{n} .3$.

37 See Mitchell, supra note 32, at 480: "The analogy of the dispositions made by testators is some answer but not a conclusive one. It must be remembered that the testator who leaves his estate to his widow does so knowing the facts, and knowing his widow. In making a universal 'will' the law ignores these factors, and there are good grounds for the law being more cautious than an individual dealing with his own property at his own risk." 
$\$ 10,000.3872 .3$ per cent had a stated value of less than $\$ 25,000$. Of the estates in which the stated value was given, out of 159,46 had a stated value of less than $\$ 5,000$ and 22 had a stated value between $\$ 5,000$ and $\$ 10,000$. Ten, or 6.2 per cent, of the estates had a stated value of $\$ 100,000$ or over.

In the sample the average stated value of worth on death for all testate estates probated was $\$ 41,885$ and for intestate estates the average value was $\$ 7,920$. In 1953 the mean testate estate was $\$ 15,000$ and the mean intestate estate was $\$ 4,000$. The 1957 figure was substantially higher for the testate estates where the mean figure was $\$ 22,000$ compared with $\$ 5,000$ for intestate estates. 39 In both years the modal size of estates, that is, the figure that had the largest number of estates in that category, was $\$ 1,000$ for both testate and intestate estates.

Perhaps the most significant feature of this analysis may be recalled if it is noted that only 15 per cent of the adult deaths were deaths of people who seemed to have accumulated sufficient capital during their lifetimes to have an estate admitted to probate. But, when this is projected for the total adult deaths in Cook County, then 95 per cent of the adults in Chicago accumulate property worth less than $\$ 10,000$ during their lifetimes. 40 Only 1 per cent accumulate property worth more than $\$ 100,000$ during their lifetimes.

\section{B. Non-probate Assets of Deceased}

Twelve of the 1957 estates, selected at random, in which an inheritance tax was reported as paid were examined further by looking at the inheritance tax returns filed elsewhere in the public records. The purpose of this examination was to determine the extent to which a deceased died with taxable assets that were not included within the probate estate. Thus property held in joint tenancy is taxable but is not includible in the probate estate. However, life insurance is not shown in either record.

In the sample of 12 estates 5 had only probate property on which inheritance taxes were paid.

In these 12 estates, $\$ 1,259,570.30$ was the net probate estate for tax purposes and $\$ 109,770.66$ was the value of the non-probate but taxable estate. The non-probate wealth represented 9 per cent of the total wealth passed by the probate estates. In the estates that had both types of taxable wealth the non-probate wealth represented 16 per cent of the total.

3s The Wisconsin Study at 399, 401 indicated that $45.3 \%$ of people having an estate had a net worth on death of less than $\$ 5,000$. Only $3.13 \%$ of the Wisconsin estates exceeded $\$ 50,000$. These dollars are not the same as 1953 or 1957 dollars.

39 The Wisconsin Study at 400-01 found an average net worth on death of all estates probated of $\$ 11,500$. This study used figures obtained from the inheritance tax returns so as to include in the net worth figures the face value of all life insurance disclosed on the tax return.

40 The Wisconsin Study at 400 indicated that $77 \%$ of the people of Dane County accumulated property worth less than $\$ 5,000$. 
In the 7 estates that had taxable estates outside of the probate estate, 6 had property includible in the inheritance tax estate because it was held in joint tenancy. There were 2 estates that had taxable property by reason of gifts in contemplation of death and one of these also had property held in joint tenancy.

While 32.7 per cent of the total value of the non-probate assets passed in the intestate estates, only 5.2 per cent of the total probate value passed in the same estates. Thus the intestate estates were more likely to have non-probate assets than were the other estates. This would seem to warrant a conclusion that the planning involved in the preparation of a will is likely to reduce the estates with taxable but non-probate assets.

TABLE 10

Percentage of Estates with ONe OR Two Types of Selected Assets (Percentages referring to estates with only one type of asset are italicized.)

\begin{tabular}{|c|c|c|c|c|c|c|c|c|c|}
\hline & \multirow{2}{*}{$\begin{array}{l}\text { FAariLY } \\
\text { RESII- } \\
\text { DENCE }\end{array}$} & \multirow{2}{*}{$\begin{array}{c}\text { INCOANE } \\
\text { REAI } \\
\text { ESTATE }\end{array}$} & \multirow{2}{*}{$\underset{\text { ESTAIE }}{\operatorname{OTHER}_{\text {TIML }}}$} & \multirow{2}{*}{ Srocrs } & \multirow{2}{*}{$\begin{array}{l}\text { GOV- } \\
\text { ERN- } \\
\text { AIENT } \\
\text { BONDS }\end{array}$} & \multirow{2}{*}{$\underset{\text { BAN- }}{\text { ACUNI }}$} & \multicolumn{3}{|c|}{$\begin{array}{c}\text { PERCENTAGE OF ESTATES } \\
\text { HAVING THE INDICATED } \\
\text { ASSET (ALONE OR IN } \\
\text { COATBNATION) }\end{array}$} \\
\hline & & & & & & & Testate & $\begin{array}{l}\text { Intes- } \\
\text { tate }\end{array}$ & Total \\
\hline $\begin{array}{l}\text { Family Residence...... } \\
\text { Income Real Estate... } \\
\text { Other Real Estate . . } \\
\text { Stocks. } \\
\text { Government Bonds..... } \\
\text { Bank Accounts*.. .... }\end{array}$ & $\begin{array}{r}6 \\
13 \\
17 \\
48 \\
30 \\
26\end{array}$ & $\begin{array}{r}9 \\
32 \\
18 \\
30 \\
29 \\
32\end{array}$ & $\begin{array}{r}18 \\
27 \\
9 \\
50 \\
18 \\
50\end{array}$ & $\begin{array}{l}15 \\
13 \\
15 \\
14 \\
32 \\
53\end{array}$ & $\begin{array}{r}18 \\
25 \\
10 \\
60 \\
2 \\
70\end{array}$ & $\begin{array}{l}8 \\
15 \\
15 \\
51 \\
37 \\
22\end{array}$ & $\begin{array}{l}16 \\
31 \\
13 \\
34 \\
33 \\
50\end{array}$ & $\begin{array}{r}10 \\
6 \\
10 \\
29 \\
11 \\
37\end{array}$ & $\begin{array}{l}13 \\
20 \\
13 \\
44 \\
23 \\
45\end{array}$ \\
\hline $\begin{array}{l}\text { Number of Estates } \\
(=100 \text { per cent }) . \\
\text { Percentage Testate in } \\
\text { Group.............. }\end{array}$ & $\begin{array}{l}(23) \\
70\end{array}$ & $\begin{array}{l}(34) \\
88\end{array}$ & $\begin{array}{l}(22) \\
68\end{array}$ & $\begin{array}{l}(74) \\
72\end{array}$ & $\begin{array}{l}(40) \\
80\end{array}$ & $\begin{array}{l}(76) \\
65\end{array}$ & (98) & (72) & $(170)$ \\
\hline
\end{tabular}

* $\$ 1,000$ or more.

The conclusion that 8 per cent of the total taxable wealth passed outside of the probate estate does not permit a conclusion as to the total amount of wealth that is transmitted at death outside of the probate estate. Life insurance under the Illinois procedure is not taxable on death so that we have no information available as to the amount of wealth that passes in the form of life insurance.

\section{Composition of Estates}

Table 10 shows the percentage of estates with one or more of a selected type of asset. It is to be read from left to right as indicating in the first column the percentage of estates that had only the enumerated asset and in subsequent columns the percentage with one of several other assets. The three columns at the right indicate the proportion of estates which had the asset listed at the left. Thus 13 per cent of the estates had family residences. The last line in the Table indicates the differences in proportion of testacies depending on the type of selected asset. 
The Table vividly shows the decline of real estate as a significant asset in the decedent's estate. Fifty per cent had no real estate in the inventory, and, if the family residence is excluded as an item of investment, only 33 per cent had investment real estate. Forty-four per cent of the estates had either publicly or closely held stocks in the inventory, and about the same number had bank accounts, including shares of savings and loan associations. One out of four estates had government bonds in the portfolio. Estates with stock in the portfolio appear to be the most liquid since more than one-half of these estates also had bank accounts of more than $\$ 1,000$. Estates with real estate had the lowest percentages invested in bank accounts.

Table 10 also gives some indication of the influence of the type of asset on a tendency toward testamentary disposition. Holders of bank accounts and single family residences were testate only about as often as for estates as a whole. Holders of income-producing real estate had the highest propensity toward testacy. This could indicate that the difficulties of fragmentation of ownership of investment real estate are one factor tending to induce the use of a will. Another significant factor shown by this Table is that testate estates are likely to be much more complicated than intestate estates. The proportion of intestate estates having a single asset is shown by the fact that the total percentage for such estates is only slightly more than 100 per cent. For testate estates the proportion having the enumerated asset totals 200 per cent, thus indicating the prevalence of combinations in such estates.

Since the bulk of life insurance does not pass through the estate it was impossible to determine the extent of life insurance holdings by the decedents in the sample.

\section{Tort Claims}

An analysis of the 1957 estates in which a tort action was an asset of the estate is revealing as to the function of estate administration. There were 5 estates that listed a tort injury as a basis or asset for the appointment of an administrator. Of these 5,1 was testate and 4 were intestate estates. Of the 5 estates, 2 proceeded with regular administration in that other assets were also administered. One of the 2 was the only such testate estate in which the deceased was a proprietor; the other was an intestate estate in which the deceased was a salesman. The 3 intestate estates in which no other assets were administered reported that the judgments recovered were $\$ 7,500, \$ 7,000$ and $\$ 1,500$ respectively. In 2 of the 3 estates the injury received in the accident was the cause of death. The 1 in which it was not the cause of death according to the death certificate was the estate in which the recovery of the tort claim was the smallest, $\$ 1,500$.

The absence of other assets in the 3 estates presents an interesting commentary on practices in small estate distribution. The small estate law of Illinois under which heirs may recover a total amount of up to $\$ 3,000$ from persons 
owing the deceased money or possessing or controlling other property of the deceased requires an affidavit by an heir stating that "no letters are then outstanding on the estate in this state and no petition for letters is then pending in this state." 41 The affidavit also must state that the gross value of the personal estate does not exceed the sum of $\$ 3,000$. Since the tort claim is not technically an asset of the estate it is possible that even in the 2 estates in which the tort judgment was more than $\$ 7,000$ the small estate statute was used by heirs to collect other sums due the deceased. But in order to do this the affidavit must state that there are no letters of administration outstanding. Such an affidavit could be filed truthfully if the other assets were collected before the administrator was appointed. In 1 of these estates the administrator was appointed 75 days after death so that the heirs could have collected other sums due the deceased in this period. In the 1 with the largest tort claim, however, the estate was opened less than 30 days after death and since the small estate law requires the affiant to state that 30 days have elapsed since death this was impossible. It is, of course, possible that the deceased had no assets in either of these 2 cases. One was an employee of the Chicago Park District and the other was a maintenance worker in a manufacturing establishment. Since both of these intestate deceased were employees, it is highly unlikely that there were no other assets because unpaid wages were a possibility; and, in the case of the park district employee, some death benefit and pension rights may have been available. How then could the heirs of the deceased collect the unpaid wages and the like? Several possibilities suggest themselves: It is possible that the heirs did not know that unpaid wages could be obtained from the employer; it is possible that the heirs waited until the estate involving the tort action was closed, but if they did this the administrator appointed in the tort action probate proceeding was derelict of duty in not collecting these sums. It is possible that the comptroller or paymaster of the employer of the deceased made payments to an heir or spouse without requiring the affidavit. Since this is quite frequently done for small amounts, this is a real possibility in the 2 estates involved. Finally, since the comptroller or paymaster is not required to examine the truthfulness of the affidavit, it is possible that the heirs made use of the small estates procedure by asserting that there were no pending probate proceedings, filed the affidavit with the debtor of the deceased and obtained payment directly rather than using the probate proceeding. It is not possible to obtain information as to what was actually done in the situations examined but they do suggest the possibility of using the small claims procedure through improper affidavits. In 1 of the 3 estates with no other assets, there was a spouse surviving, in 1 there was a daughter surviving but in the third there were 4 brothers and sisters surviving. In the 2 estates with only the daughter or spouse surviving, any debtor of the deceased could pay the daughter or the spouse as the sole heir entitled to payment, but if the small

41 ILl. Rev. STAT. ch. 3, § 324 (1961). 
estates procedure was used in the 1 with surviving brothers and sisters, if the affidavits were truthful, the debtors were required to divide any sums due the deceased into 4 parts with separate payments to each of the 4 brothers and sisters.

\section{The Process of Administration}

\section{A. The Time Consumed}

For intestate estates there are two periods of time required to close an estate: First, the time between the date of death and the time at which some person, usually a relative, opens the proceedings; and second, the time between the opening of the proceedings and the date of closing. For testate estates there are three periods of time. Under the statutes of Illinois there is a civil penalty if a person having a will in his possession fails to file it within 30 days of death. 42 Filing does not open the estate, however, so there is a second period of time between the date of filing and the date of opening to consider. Finally, there is the period of time between the opening of the estate and the closing. Notwithstanding the date that appears in the probate records as the date of closing, there is considerable uncertainty as to the "real" date of closing of estates. If all of the claimants are competent and agreed, there is no necessity of any formal closing of an estate as far as distribution and certainty of title are concerned for all of the participants in the proceeding can execute releases consenting to a distribution which the personal representative makes and consenting to any payment of attorneys' or executors' fees. If this method of proceeding is used then the estate may appear on the public records to be open many months or years after it is in fact closed and indeed may appear to be open until a probate judge has his records examined to determine whether estates that should have been closed are still open. Probate judges vary in the amount of energy that they devote to this special task. Even if a formal closing date appears in the records the real closing date may be earlier than this, for if everything is ready for distribution and the executor foresees no difficulty, he may distribute without a formal closing and then at his own convenience complete the necessary papers to have a formal closing.

For intestate estates the average time between the date of death and the date of opening a proceeding was less than 2 months and the modal timethat is, the time most frequently occurring-was less than 15 days. For testate estates the average time between the date of death and the date the will is admitted to probate was between $21 / 2$ and 3 months, and the modal time was between 2 and $2 \frac{1}{2}$ months.

How effective is the requirement, subject to penalty, that a will be "filed" within 30 days of death? Eighty-two per cent were filed within 30 days of death. This high percentage meeting the statutory requirement could be interpreted as proof of the deterrent effect of the statute. If a comparison is made with the time for intestate estates where there is no statutory requirement for

42 ILL. Rev. STAT. ch. 3, § 60 (1961). 
some action in connection with the Probate Court, 57 per cent of the estates were opened in the same period. In 1957, 16, or 61.5 per cent, of the 26 intestate estates were opened within 30 days of death; and in 1953, 20, or 52.6 per cent, of the 38 intestate estates were opened within 30 days of death. The first act in connection with the Probate Court thus does seem to occur more readily in the case of testate estates than in the case of intestate estates.

For the time between opening an estate and its closing there is a statutory minimum of 9 months after issuance of letters testamentary if regular probate proceedings are used. This minimum exists because of the requirement for advertisement for creditors to file claims and the statutory period in which creditors are permitted to file claims. 43 Table 11 shows the average time in

TABLE 11

Average Time in Months Elapsed Between Opening and Closing of Estates by Value and Type of Probate 1953 AND 1957

\begin{tabular}{|c|c|c|c|c|c|c|c|c|c|c|}
\hline & & \multicolumn{7}{|c|}{ VALUE OF ESTATE } & \multicolumn{2}{|c|}{ Total. } \\
\hline & & $\begin{array}{l}\text { Below } \\
5,000\end{array}$ & $\begin{array}{l}5,000- \\
9,999\end{array}$ & $\begin{array}{c}10,000- \\
14,909\end{array}$ & $\begin{array}{c}15,000- \\
24,999\end{array}$ & $\begin{array}{c}25,000- \\
49,999\end{array}$ & $\begin{array}{c}50,000- \\
99,999\end{array}$ & $\begin{array}{c}100,000 \\
\text { and } \\
\text { over }\end{array}$ & $\begin{array}{c}\text { Average } \\
\text { (Miean) }\end{array}$ & Mode \\
\hline Intestate.. & $\left\{\begin{array}{l}1953 \\
1957\end{array}\right.$ & $\begin{array}{l}22 \\
11\end{array}$ & $\begin{array}{l}22 \\
12\end{array}$ & $\begin{array}{l}15 \\
11\end{array}$ & $\begin{array}{l}11 \\
14\end{array}$ & ${ }^{\prime} \overline{i t}^{\cdots}$ & $\ldots \ldots \ldots$ & $\ldots \ldots \ldots$ & $\begin{array}{l}19 \\
11\end{array}$ & $\begin{array}{l}12 \\
10\end{array}$ \\
\hline Testate .. & $\left\{\begin{array}{l}1953 \\
1957\end{array}\right.$ & $\begin{array}{l}20 \\
14 \\
\end{array}$ & $\begin{array}{l}21 \\
13 \\
\end{array}$ & $\begin{array}{l}12 \\
12\end{array}$ & $\begin{array}{l}15 \\
14\end{array}$ & $\begin{array}{l}16 \\
14 \\
\end{array}$ & $\begin{array}{l}15 \\
21\end{array}$ & $\begin{array}{l}24 \\
20\end{array}$ & $\begin{array}{l}17 \\
15\end{array}$ & $\begin{array}{l}11 \\
12 \\
\end{array}$ \\
\hline Total & $\left\{\begin{array}{l}1953 \\
1957\end{array}\right.$ & $\begin{array}{l}21 \\
12\end{array}$ & $\begin{array}{l}21 \\
13\end{array}$ & $\begin{array}{l}13 \\
12\end{array}$ & $\begin{array}{l}14 \\
14\end{array}$ & $\begin{array}{l}16 \\
15\end{array}$ & $\begin{array}{l}15 \\
21\end{array}$ & $\begin{array}{l}24 \\
20\end{array}$ & $\begin{array}{l}18 \\
13\end{array}$ & $\begin{array}{l}11 \\
10\end{array}$ \\
\hline
\end{tabular}

months to close estates with various stated amounts of value and it also shows the mean and mode for all estates. ${ }^{44}$ Since the modal time is 10 months it would appear that many estates are closed at about the statutory minimum. If estates can be closed so quickly after administration can begin in earnest, a question is raised as to whether the period now provided in the statute may be too long. As the Table indicates the estate of less than $\$ 5,000$ and the estate of more than $\$ 100,000$ took more time to close than the estates in the middle ranges of stated values. Estates of a value between $\$ 10,000$ and $\$ 25,000$ took the least amount of time in the sample. The average time to close estates with real estate in the combined sample was between 15 and 16 months, and for estates without real estate just under 15 months, so that it would appear that there is no substantial difference in the time necessary to close an estate with real estate and one without real estate. 45

43 IIL. REv. STAT. ch. 3, § 204 (1961).

44 The Wisconsin Study at 403 showed average times to close estates ranging from 11.08 months for those less than $\$ 2,000$ and 9.65 months for those more than $\$ 20,000$.

45 The Wisconsin Study at 403 showed an average of 12.7 months for estates with real estate and 9.9 months for estates without. 
Table 12 breaks the average times into categories according to the nature of the personal representative and according to value. The "best" personal representatives in terms of time necessary to administer an estate were children, and brothers and sisters, but in the estates of lesser value a corporation was the least expensive in time. In the smaller estates the spouse and strangers (which include lawyers) consumed the most time. Within the category of "strangers" was a large percentage of lawyers serving as personal representatives, and it should be noted that the stranger-personal representative took more time to close an estate than the corporate-personal representative. Another point of comparison is between the paid and the unpaid representative. Since the paid representative cannot obtain his fee until the time the estate is closed, there would appear to be a special inducement for him to rush the probate proceedings. In both years, however, the paid representative took more time than the total average. This may be explainable on the basis of the

TABLE 12

Average Time in Months to Close an Estate acCORding to Valuation AND TyPE OF PERSONAL REPRESENTATIVE, 1953 AND 1957

\begin{tabular}{|c|c|c|c|c|c|c|}
\hline \multirow[b]{2}{*}{ VAruE } & \multicolumn{6}{|c|}{ TyPE of REPREsentative } \\
\hline & Spouse & Children & $\begin{array}{l}\text { Brothers, } \\
\text { Sisters, and } \\
\text { Descendants }\end{array}$ & Strangers & Corp. & Paid \\
\hline $\begin{array}{l}\text { Under } \$ 25,000 \ldots \ldots \\
\text { Over } \$ 25,000 \ldots \ldots\end{array}$ & $\begin{array}{l}16 \\
15.2\end{array}$ & $\begin{array}{l}13.9 \\
15.7\end{array}$ & $\begin{array}{l}12.6 \\
16.3\end{array}$ & $\begin{array}{l}15.8 \\
17.2\end{array}$ & $\begin{array}{l}11.5 \\
18.5\end{array}$ & $\begin{array}{l}15.4 \\
18.4\end{array}$ \\
\hline Total... & 15.6 & 14.8 & 14.5 & 16.5 & 15 & 16.9 \\
\hline
\end{tabular}

earlier conclusion that the paid representative is more likely to be utilized for an estate of larger dollar value and therefore a more complex type of estate. The slowness with which a spouse closes an estate is also a matter of interest for this may indicate that the spouse in a large number of cases continues to treat the property of the decedent almost as he or she did as a member of the family during the life of the owner.

The 2 estates in 1953 administered by the public trustee produced an average time of 22 months, much longer than the general average or the average time for any other type of personal representative.

Can anything be done to reduce the time involved in closing estates? There would appear from the above statistics to be no undue delay in opening an estate after the death of the owner and likewise no undue delay in the closing of an estate when one considers that there is the statutory minimum of 9 months. Small estates do appear to take a long time. There would seem to be therefore only two methods by which substantial reductions in the amount of time necessary to close an estate could be achieved: (1) by a substantial in- 
crease in the availability of the "summary" probate proceedings for small estates, that is, by increasing the kinds of estates that may use the summary procedure, and (2) by a substantial shortening of the time given a creditor to file a statement of his claim. No information is available from the records as to the kinds of debts that are proved in the probate proceedings. If the bulk of these debts are the typical monthly charge accounts and installment selling contracts, it would appear that there could be a substantial reduction in the time needed in order to acquaint creditors of this type with the fact that their debtor is now dead. If the time for filing claims were substantially reduced, it is possible that services of a business nature would be established, publishing to creditors the names and addresses of every resident of the county who dies, to which creditors for a fee could subscribe in order to acquire information at the earliest possible time of the death of the debtor. With modern methods of publication and notice to possible claimants, it would seem that 9 months is too long a period of time.

A decrease in time could also be achieved by increasing the types of estates for which summary treatment is possible. At the time of the estates under consideration, the Illinois Small Estates Act 46 imposed a number of limitations on the use of summary closing that are important to our consideration here: First, the Small Estates Act is limited to situations where a person or corporation is "indebted to or holding personal estate of a decedent" or has "the responsibility for the issuance or transfer of stocks [or] bonds" of the decedent. Secondly, it is required that the decedent die a resident of Illinois. Thirdly, the decedent must die without creditors. And finally, the gross value of the personal estate must not exceed the sum of $\$ 1,000$.

An analysis was made of the 1957 estates that had a value of less than $\$ 10,000$ to determine whether the summary procedure could be made available to these estates. More than one-third of the total number of estates of 1957 examined fell into this category.

There were 25 such estates in all, 8 testate and 17 intestate. In the testate estates there was no land involved and the primary asset of the estate in 7 of the 8 was some kind of an institutional debt such as a bank account, bond or stock. Stock was the primary asset in 50 per cent of the 8 estates. Thus 7 of the 8 estates could qualify for small estate treatment as far as type of asset was concerned. One of the 8 involved an out-of-state estate in which the decedent was an heir or legatee and presumably the out-of-state personal representative required an estate to be opened in Illinois before he would make distribution to the claimants through the deceased heir or legatee of his estate. Three of the 8 estates could not qualify for small estate treatment because they had creditors for debts other than funeral expenses. In 1 estate where mineral company stock was listed as an asset of the estate the value was not shown so

\footnotetext{
46 ILL. REv. STAT. ch. 3, $\S \S 478-82$ (1953). Since this date the sections have been rewritten and the gross value raised to $\$ 3,000$.
} 
it cannot be determined whether the estate could qualify for small estate treatment as far as value is concerned.

In the testate estate there was 1 surviving spouse who was given all by the will and 1 estate with surviving children who were given all by the will. In the remaining 6 estates there were brothers and sisters and the will primarily functioned to exclude brothers and sisters or descendants of brothers and sisters.

After payment of all claims in the 8 estates, there were 3 that had a net worth available for distribution of $\$ 4,000$ or more; there were 3 that had a net worth of less than $\$ 1,500$; and there was 1 with a deficit. There was no information as to the remaining testate estate.

Of the 17 intestate estates land was involved in 2 , and the primary asset in 4 was a cause of action so that 6 of the 17 estates could not qualify for small estate treatment regardless of the other statutory requirements. In 10 of the 17 estates, however, an institutional debtor or a corporation was involved in the primary asset so that as far as types of assets were concerned these estates could qualify for the small estate treatment. Six of the 17 estates could not qualify for small estate treatment because the gross estate exceeded $\$ 1,000$ and 4 could not qualify because there were debts other than funeral expenses. In the 13 estates other than those having a tort action as their principal asset, there was a deficit in 1 , and 2 did not show the net worth available for distribution. Four had a net worth of less than $\$ 1,000$, and 2 had a net worth of $\$ 3,000$ and more.

A conclusion that may be drawn from this analysis of the small estate procedure is that while an increase in the maximum amount of the gross estate would be of some value in eliminating these estates from probate proceedings, more substantial changes are needed in order to make a small estate procedure more effective. The substantial differences between the net worth and the gross amount stated in the estates analyzed would indicate that a substantial number of people with small amounts of accumulated wealth die with debts outstanding. Under the present acts, a probate proceeding is required unless the claimant was willing to pay the debts himself and then state that there were no creditors of the decedent. The records do not permit an examination of the possible effect of a change in procedure that would allow a claimant to receive payment from the institutional debtor even though there were outstanding debts if he expressly assumed the debts of the decedent and notified the creditors known to him that such an assumption had occurred. This would impose an increased risk on creditors.

\section{B. Cost of Administration}

1. General.--Some of the expenses incurred in settling estates are the same for all of them regardless of their size. For example, the cost of giving notice 
and some of the court costs are fixed by statute so that the amount is the same regardless of the size of the estate. Thus the fee fixed by the statute or probate code of Illinois for appraisers is $\$ 2$ per day for each appraiser. ${ }^{47}$ Although it is possible for the estate to pay more, the 1953 statistics would indicate that it is seldom that the estate pays more. In the 1953 sample, out of 20 estates for which the information was available, only 5 , or 25 per cent, listed as an expense an appraiser's fee of more than $\$ 6$. The estates in the sample from which this information is taken varied in size from $\$ 3,500$ to $\$ 180,000$. In the few estates in which a guardian ad litem was appointed it also appears that the fee tends to be a standardized sum and does not vary substantially with the size of the estate. In the 6 estates in 1953 in which a guardian ad litem was required, the fee of the guardian represented not more than .3 per cent of the estate. The fee varied from $\$ 40$ to $\$ 125$. Because so many of the court costs are fixed in amount these expenses vary inversely with the size of the estate. Table 13, indicating the percentage of the gross estates spent for selected types of expenses, reveals that, with the exception of estates under $\$ 5,000$, there is no substantial difference in court costs between a testate and an intestate estate.

2. Funeral expenses.-One of the most interesting features of the analysis of the costs of administration is the frequency with which relatives choose to hold expensive funerals for the deceased person without regard to the financial position of the decedent. Social standards of the decedent seem to be more significant than the monetary value of his estate in the selection of the type of funeral to be had. Thus in estates with a gross value of more than $\$ 50,000$ less than 5 per cent was spent for funeral expenses, whereas in 8 estates of less than $\$ 5,000$ as much as 40 per cent was spent for funeral expenses. An analysis of the 1957 sample indicates that the average cost of the funeral is $\$ 1,086.01$; the mean cost is between $\$ 900$ and $\$ 999$ and the modal cost is $\$ 900$ to $\$ 1,299$. In this regard there is no substantial difference between the testate and intestate estates. Of the 46 estates examined, 17 had funeral costs of less than $\$ 900,5$ above $\$ 1,400$, and 24 were between $\$ 900$ and $\$ 1,400$. Approximately 43 per cent were between $\$ 900$ and $\$ 1,300$. Thus the funeral cost tends to be a relatively constant figure.

3. Compensation of personal representative.-A most striking fact indicated in the analysis of the costs of administration is the frequency with which the estate is administered by a person who does not claim a fee for his services. In the 59 estates examined in the sample for which information is available only 22 per cent of the estates had a paid personal representative. There was a striking difference between payment of an administrator and of an executor since only 4.3 per cent of the administrators were paid for their services, whereas 30 per cent of the executors were paid. This is an extremely significant fact when it is recalled that the testator may choose his representative, if he selects an executor, and indeed may provide for compensation or for no

47 ILL. Rev. Srat. ch. 3, § 176 (1961). 


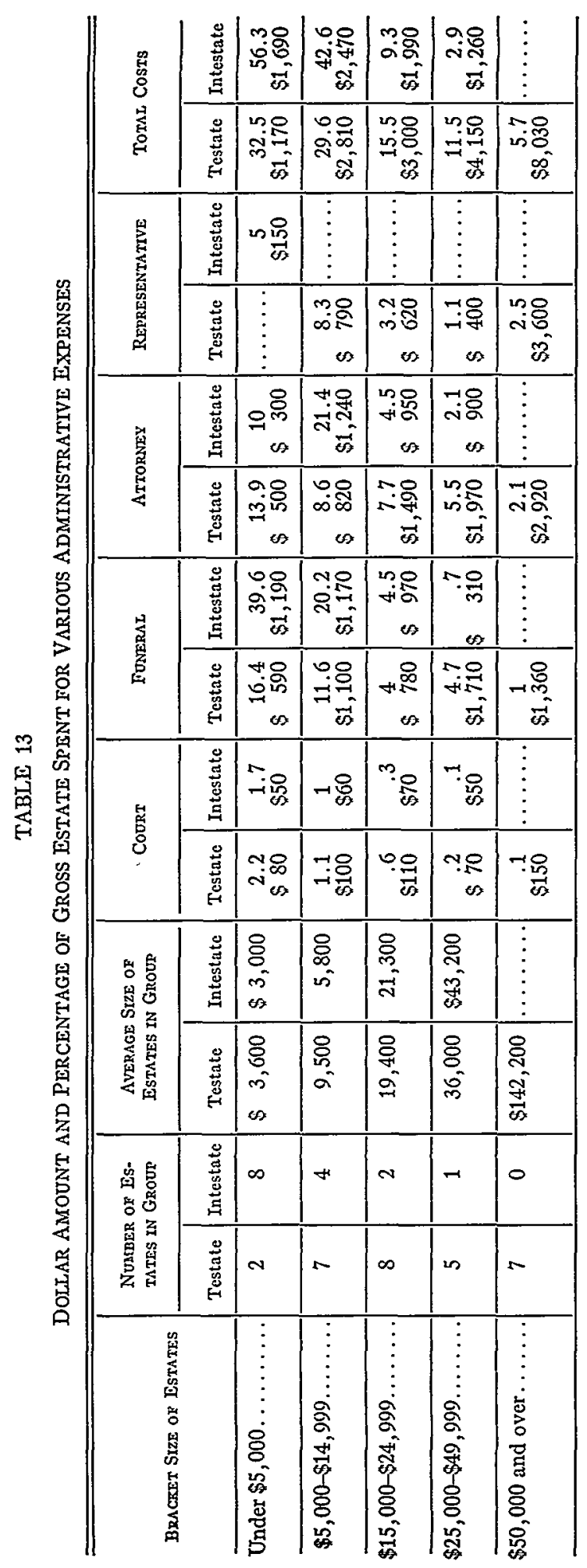


compensation as he chooses. An analysis of the personal representatives by relation to the decedent gives some indication of the significant factors in payment of the representative. No child who served as an executor received compensation and only one of the spouse-executors was paid. Of course, all of the corporate executors were paid and 78 per cent of the stranger-executors were paid. Of the 13 personal representatives who received payment, 76 per cent were more distant relatives than brothers and sisters or their descendants or they were strangers or corporations. Table 14 indicates the percentage of personal representatives receiving compensation in the 1953 and the 1957 samples.

TABLE 14

Percentage of Paid Representatives BY CLASS OF REPRESENTATIVE*

\begin{tabular}{|c|c|c|c|}
\hline & \multirow{2}{*}{$\begin{array}{c}\text { PERCENTAGE OF } \\
\text { REPRESENTATTVES } \\
\text { EN EACH GROUR } \\
\text { WHO RECETVED } \\
\text { A FEE }\end{array}$} & \multicolumn{2}{|c|}{$\begin{array}{l}\text { Total NUMBER OF REPRE- } \\
\text { SENTATIVES IN SAMIPIE }\end{array}$} \\
\hline & & Number & Percentage \\
\hline $\begin{array}{l}\text { Corporate.......... } \\
\text { Strangers.......... } \\
\text { Distant relatives.... } \\
\text { Brothers, sisters, and } \\
\text { their descendants.. } \\
\text { Children.......... } \\
\text { Spouse............ }\end{array}$ & $\begin{array}{r}100 \\
83 \\
60 \\
50 \\
12 \\
2\end{array}$ & $\begin{array}{r}(9) \\
(18) \\
(5) \\
(4) \\
(33) \\
(41)\end{array}$ & $\begin{array}{r}8 \\
16 \\
5 \\
4 \\
4 \\
30 \\
37\end{array}$ \\
\hline Average. . . . . . & 31 & (110) & 100 \\
\hline
\end{tabular}

* 1953 and 1957 data combined.

The absence of compensation for the personal representative cannot be completely explained on the basis of the relationship of the representative to the deceased or on the basis of the wish of the deceased in the testate estates. Thus if the personal representative is also the sole legatee or sole heir in an intestate estate, it makes no difference so far as a solvent estate is concerned whether the distributee receives two sums, one representing compensation for service as personal representative and the other representing the net sum available for distribution, or receives only one sum as distributee. To the representative there may be a difference so far as his own federal taxes are concerned. Sums received as compensation as a personal representative are taxable to the representative as income, whereas sums received as part of the distributed estate are not taxable income. On the other hand, from the state inheritance tax and the federal estate tax point of view, sums paid to the distributees are not deductible in calculating the tax, whereas sums paid to the distributee as compensation to him as personal representative are a deductible expense of administration. There may be other factors influencing the personal represent- 
ative's own decision whether to waive compensation or to claim it. If the estate is insolvent the personal representative who is also a distributee might get something if he claims compensation for his services since this is a class of claim against the estate that is entitled to high priority of payment. In one case the personal representative had previously assigned his distributee's share of the estate to a third person (a divorced spouse) and he was able to reduce the sums to which the assignee was entitled by claiming compensation for his services as personal representative. In spite of all these possible reasons for claiming compensation, the most significant factor seems to be the closeness of relationship to the decedent. Corporations and those individuals more distant from the deceased than brothers and sisters and their descendants comprised 25 per cent of the total personal representatives and account for 65 per cent of the representatives who claim compensation for their services. When brothers and sisters and their descendants are added to this category approximately 50 per cent of the personal representatives by classes of relationship furnished almost 90 per cent of the personal representatives claiming compensation; although a spouse and children furnished 50 per cent of the personal representatives, they account for only 10 per cent of the representatives who received compensation.

Table 14 also gives us some indication as to the class of possible personal representatives with whom a corporate executor in the business of serving as representative is in competition. While corporate representatives served in only 6.2 per cent of the total cases, 48 corporate representatives constituted 25 per cent of the total numbers of representatives more distant from the deceased than brothers and sisters and their descendants. If the corporate representative is compared with the class of representatives entitled "strangers," which includes not only attorneys but other strangers to the deceased such as an ex-wife, the corporate representative had one-third of the estates.

The table also gives some indication of the difficulties corporate representatives face in their public relations and advertising campaigns urging persons to use corporate executors and administrators. Since the great bulk of the personal representatives receive no compensation for their services, particularly where there is a surviving child or spouse, it is not surprising that a corporation, which always gets paid for its services, does not fare well in competition with a representative who receives no compensation.

4. Attorney's fees.-The Chicago Bar Association has a scale of recommended attorneys' fees for the attorney of an estate. These are calculated on

4899 TRUSTS \& EsTATES 414 (1960) reports a 1959 survey in Cook County, Illinois, showing that in $6 \%$ of the Cook County wills there was a corporate executor. An earlier survey of Cook County probate records recorded a decline from a high of $13.6 \%$ in 1930 . In 1950 corporations had $10.5 \%$ of the executorships. 
the basis of the gross estate.49 Do Chicago attorneys charge a fee recommended by the Association of which many of them are members? It is diffcult to answer this question because of the large number of estates in which the documents in the probate records do not show the gross value of the estates. It appears customary in the Chicago area not to put a value on stocks and bonds except in the unusual situation where such items must be sold. Where distribution is made in kind the value does not appear in the public records. In the 1953 and 1957 samples, 68 estates were found in which there appears to be adequate information to permit a tentative conclusion as to the relation of the fee actually charged to the Bar Association scale. If we assume that a fee that varies between 97 per cent and 103 per cent of the fee which should be charged according to the Bar Association scale is substantially the fee recommended by the Bar Association and that the variance may be explained by errors, "rounding" practices, or some items not being included in the Bar Association scale, then it would appear that in the testate estates the fee allowed substantially deviated from the Bar Association scale. In the 30 testate estates in the sample of 68,33 per cent reported attorneys' fees substantially the same as the Bar Association scale. In 20 per cent of the testate estates the fee charged was substantially more than the Bar Association scale but in almost 50 per cent of the testate estates the fee charged was substantially less than that which the Bar Association recommended. In the 20 testate estates where there was a substantial departure from the Bar Association scale, 70 per cent departed from the Bar Association rule by charging less than the scale would have permitted. A similar conclusion may be drawn from the 38 intestate estates. In this group 45 per cent reported fees substantially equivalent to the Bar Association scale and 10 per cent had fees that were substantially more than the Bar Association recommended. Thus 45 per cent of the intestate estates had fees that were substantially less than those recommended by the Bar Association. In the 21 intestate estates where there was a substantial departure from the Bar Association scale, 86 per cent deviated downward. Putting the testate and the intestate estates together, we find that in the total of 68 estates where the information is available 46 per cent showed fees less than the Bar Association scale. These statistics do not, of course, indicate whether it is the judge who is requiring a substantially lower fee than the Bar Association scale or whether it is the lawyer who is asking the lower fee. The figures are also susceptible to error because of the skimpiness of

49 The scale in 1957 was as follows:
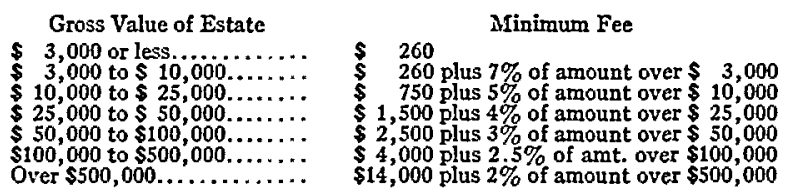
the records available concerning the gross estate. It is believed, however, that in spite of these difficulties the conclusion that one can draw from this sample is that in either testate or intestate estates over one-half the lawyers received a fee different from that which would have been charged if the Bar Association scale had been followed. The difficulties of maintaining the Bar Association scale in a segment of the Bar where competition is high may be further confirmed if it is noted that in neither the 1953 sample of 97 estates nor in the 1957 sample of 73 estates did any one lawyer or law firm have more than one probated estate. The large number of lawyers thus available for probate work would, according to traditional economic analysis, suggest that the recommended scale of fees is not readily enforceable. This large supply of lawyers available to do probate work may be contrasted with the number of lawyers handling personal injury litigation. 50

The 8 of the 15 testate estates in 1957 for which fee information is available and which deviated from the Bar Association scale by 15 per cent or more were examined in order to determine the factors that seem to be significant in deviation. Two of the 8 estates involved deviation upward; in 1 the fee was 15 per cent above the scale and in the other the fee was 38 per cent above the scale. Two of the 3 estates in the total category of 15 in which real estate was sold by the executor fell in this category of fees above the Bar Association scale. All of the estates in which 5 or more different kinds of stocks were owned fell in this category of a fee 15 per cent or more above the Bar Association scale.

The 6 estates in which the fee was substantially below the Bar Association scale might be classified as follows: The 2 estates in which there was unsold land fell within this category and in both cases the land constituted more than 90 per cent of the gross value of the estate. Both cases also involved situations in which there was only 1 item of personal property listed in addition to the land. The remaining 4 estates in which the fee was substantially less than the scale were estates in which United States bonds and cash predominated in the list of assets. These estates, however, did not differ substantially from the bulk of the estates in which the Bar Association scale was charged. Thus of the 7 estates in which bonds were a major, if not the major, asset only 2 were estates in which the fee was substantially less than the scale.

\section{Function of Probate as a Title Proceeding}

Of the 23 estates in 1957 that had real estate as an asset, 10 were estates in which the personal property was of an amount that allowed the small estate procedure to be used. Of the 62 estates that had real estate as an asset in 1953 and 1957,25 , or 40.3 per cent, had other assets totaling less than $\$ 3,000$. In

50 Zeisel, Kalven \& BuchHolz, Delay IN THe Courts 190-200 (1959) shows an entirely different picture for personal injury litigation. $10 \%$ of the active trial bar handle $35 \%$ of all trials. 
these estates, 40 per cent-if real estate had not been present-might have used the small estates feature of the Illinois Probate Act.

\section{WILL DRAFTING}

\section{A. Age of Will and Its Author}

The wills in the two sample years were examined to determine the age of the wills at the time of testator's death. One-third of the wills were less than oneyear old. Over one-half of the wills were less than three years old. Ninety per cent of the wills were less than ten years old. Table 15 reports the age of wills in statistical form. The modal age, that is the age with the largest frequency, was less than one year. 51 Two interesting speculations as to the freshness of the

TABLE 15

\begin{tabular}{|c|c|}
\hline \multicolumn{2}{|c|}{$\begin{array}{c}\text { NUMBER OF YEARS ELAPSED SINCE } \\
\text { WIIL WAS MADE* }\end{array}$} \\
\hline Time Elapsed in Years & $\begin{array}{l}\text { roportion of Wills } \\
\text { in each Group } \\
\text { (Percentage) }\end{array}$ \\
\hline Less than $1, \ldots \ldots \ldots \ldots \ldots \ldots$ & 36 \\
\hline 1 up to $3 \ldots \ldots \ldots \ldots \ldots \ldots \ldots$ & 17 \\
\hline 3 up to $5 \ldots \ldots \ldots \ldots \ldots \ldots \ldots$ & 16 \\
\hline 5 up to $10 \ldots \ldots \ldots \ldots \ldots \ldots$ & 21 \\
\hline 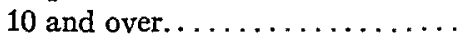 & 10 \\
\hline$\ldots, \ldots, \ldots$ & $\begin{array}{l}100 \\
49 \text { years }\end{array}$ \\
\hline * 1953 and 1957 data combined. & \\
\hline
\end{tabular}

wills are possible. Since almost three-fourths of the wills less than one year old were executed within six months of death we could believe that the decedents did not think of a will until shortly before death. An opposite explanation is also possible: The wills are fresh because the decedent kept his will, family and capital accumulations under constant review. If this latter explanation is correct then we also have a commentary on the methods used by the bulk of lawyers in revising a will, for in the category of wills executed within one year was counted the date since the last codicil and in only 2 cases in each of the years were codicils the reason for the freshness of the will. This means that, if the second explanation is the correct one, most lawyers execute completely new wills when they have the opportunity.

The age of the testator when the will is executed, as distinguished from his age at death, also reveals a lack of estate planning. The average age of the testator at the time of execution of the will was 66 (at death it was 70). The

51 Otjen \& Tabst, Updating Life Insurance Settlement Options, 27 J. INs. 75 (1960), reports a sample of 773 wills probated in Milwaukee County, Wisconsin, between January 1 and January 30,1955 . In this study $24 \%$ of the wills were less than 1 year old; $49 \%$ were less than 3 years old; $52 \%$ were less than 5 years old; and $84 \%$ were less than 10 years old. The median age of all wills was exactly 3 years. The modal age was less than 1 year. 
modal age at which the bulk of the testators executed their wills in both years was between 70 and 74 (the modal age at death was 59 ). Only 6 per cent of the testators were under 45 at the time of execution of the will and over half were age sixty-five.52 This is not startling in view of the fact that the bulk of the wills are less than 1 year old and the most common age for testate deaths was between 70 and 80, as shown in the earlier tables.53 An examination of the testate estates on which federal estate taxes were paid would indicate that there is very little more planning in this size of estate than in the others for over 50 per cent of these taxable estates had wills less than two years old.

These figures on the age of wills and the age at time of execution do not of course reveal the whole story because of the possibility that there were earlier wills than those finally probated. This information is not obtainable.

\section{B. Form of Wills}

Usually wills are in one of three forms-completely typewritten, completely handwritten, or on a printed form with the blank spaces filled in either by typewriter or by hand. Printed forms are available to the public at many book shops. In the sample 10 per cent of the wills were on printed forms. ${ }^{54}$ Handwritten wills were less numerous, constituting about 2 per cent of the wills in 1953. Although Illinois does not provide for holographic wills (wills completely in the handwriting of the testator) by special form, nevertheless the survey indicates that to some extent testators write their own wills in longhand. While it is possible for a printed and even a handwritten will to be prepared on the advice of a lawyer, it is probable that this type of will is more often prepared without the advice of a lawyer than is the case where the will is completely typed. If we assume that all of the 15 wills that were either printed or handwritten were prepared without the advice of counsel and that none of the typewritten wills were prepared without the advice of counsel, then the sample would indicate that 15.3 per cent of the wills were prepared by the deceased or some non-lawyer on his behalf.

\section{Selection of Personal Representative}

Under the Illinois Probate Act if a person does not have a will the court must issue letters of administration to a personal representative selected by some statutory procedure. Section 96 of the Illinois Probate Act provides that

\footnotetext{
52 The Milwaukee survey, note 51 supra, indicated that the median age of testators at the time of making a will was 69 , the modal age was 72 . Only $3 \%$ of all wills were made when the deceased was under age $45.65 \%$ of all wills were not written until after 65 . This fact should be compared with the LIFE INSURANCE FACT BOOK which shows that $88 \%$ of all insurance has been purchased by age 45 .

53 See pp. 243-45 supra.

54 The Wisconsin Study at 420 showed the use of printed form wills in only $7.8 \%$ of the instances where testamentary disposition was made.
} 
letters of administration should be issued in a specified order either to the persons therein named or to persons nominated by them. 55

If a person leaves a will to what extent does he deviate from the order of preference provided by the statute for estates in which no personal representative is nominated? If one assumes that any executor nominated represents a deviation from the statutory order of preference whenever the person nominated is not in the closest category to the deceased, then in the sample 60 per cent of the executorships included one person who was not in the highest category of preference. In several cases where the nearest category was brothers and sisters (statutory preference (4)), the representative nominated by the deceased was a niece, that is, a child of a brother or sister (statutory preference (6)). It is possible that the brothers or sisters would have nominated the child as the administrator. Where the executor nominated was outside the immediate family, then we have the clearest case of the deceased choosing a person who might well not have been picked under the statutory scheme. The most significant factor here seems to be closeness of the family survivors. While 48 per cent of the wills involved survivors among spouse and children, only 20 per cent of the executors who were not members of the immediate family came from this class of wills. On the other hand, 80 per cent of the strangers nominated as executors were nominated where the nearest relatives of the deceased were brothers and sisters or more distant relatives. A further breakdown of the cases where a stranger was nominated as an executor would indicate the confidence that the deceased had in his close relatives. In only 1 of the 12 cases where there was a surviving spouse was a stranger nominated as executor. In the 7 cases where the nearest relative was a child, in only 1 was a stranger nominated as the sole executor. Corporate executors were nominated in 9 per cent of the wills.

That 60 per cent of the nominated executors involved some deviation from the statutory order of preference for personal representatives in the case of an intestacy indicates to some extent that one function of a will, even though the distribution ordered by the will conforms to the statutory distribution, is to nominate a representative to administer the estate. This is further borne out if one considers the situation in which a bond is to be required of the personal representative. All administrators are required to put up a bond with a third party surety. ${ }^{56}$ A deceased by his will may provide that no bond of this type is to be furnished. The effect of this on the estate is to put on the estate the risk of insolvency of the administrator, but it saves the expense of providing for a

55 The order of preference in the statute in 1953 (ILL. REV. STAT. ch. 3, \& 248) was: (1) the surviving spouse or any person nominated by him; (2) the children or any person nominated by them; (3) the father and mother or any person nominated by them; (4) the brothers and sisters or any person nominated by them; (5) the grandchildren or any person nominated by them; (6) the next of kin or any person nominated by them; (7) the public administrator; (8) a creditor of the estate.

56 ILL. REV. STAT. ch. 3, §§ 299-314 (1961). 
bond. In 1953 where the information concerning a bond is available, a bond was waived in better than 92 per cent of the cases. In the 4 cases where there was a bond, 3 of the bond requirements were imposed by the will and 1 by the fact that there was an administrator since the nominated executor could not serve. The bond seems to have been required as often, when it was required, from members of the family as from non-members. In the 7 cases where a corporate executor was provided by the will, no bond was required by the will and none is required by statute.

\section{Use of Trusts}

Trusts were not a major factor in any of the wills in either 1953 or 1957. In 1953, 9 wills mentioned trusts. Seven were present trusts and 2 were contingent trusts in case the primary legatee predeceased the testator. In 1957 there were also 9 trusts in the 40 wills. Thus for the 2 years 18.3 per cent of the wills referred to trusts. In 2 of the 18 trusts there was a corporate trustee. Eight of the 18 trusts were in estates in which an estate tax was possible. Of these, a marital deduction trust was possible in 4 of the 8 trusts and it was actually used to obtain estate tax savings in 1 of the 4 cases. The purposes that the trust served were varied. In 1953, 2 of the trusts were for the purpose of performing a specific act with respect to property such as to hold jewelry until a beneficiary reached a specified age and then to divide it among the beneficiaries. Three were to pay income to children or grandchildren until the child was educated or while the child was in the priesthood or until he reached the age of thirty. One was a trust to support an unmarried sister with whom the decedent had lived before his death, and 1 was a residuary trust to a distant relative after the bulk of the estate was given to particular charities. In 1953 there was 1 trust that could be classified as a marital deduction type of trust. A similar variation of purpose was shown in the 1957 trusts. While there were no trusts to perform a specific act with respect to property, there were 5 trusts to pay income to children and great grandchildren, 2 of which were contingent; there were 3 trusts to support brothers or sisters or their descendants, and there were 4 trusts in 1957 for the benefit of a spouse. Also in 1957 there was 1 trust that could be classified as a marital deduction type of trust.

The most striking fact about the use of trusts was the absence of any clear preponderance of trusts in favor of a surviving spouse. Thus in the 2 years examined only 4 of the trusts provided income for a surviving spouse.

\section{E. Substitution of Beneficiaries}

With respect to standard clauses in wills, both the 1957 and 1953 samples were analyzed for clauses concerning substitution in case a beneficiary predeceased the testator, clauses concerning common casualty and clauses concerning will contest. Fifty-five per cent of the wills had substitution clauses to deal with the situation where a legatee predeceased the testator. An analysis 
of the substitution clause indicates that the draftsman or the testator himself planned a substitution clause and it was not put into a will as standard "boilerplate." More than 60 per cent of these clauses were in wills where the primary legatee was a "contemporary" of the testator, such as his wife or brothers and sisters. Substitution clauses in this category should be contrasted with those used where the primary legatees were children. In 1957 only about 20 per cent of the substitution clauses involved children as the primary legatee. The prevalence of substitution clauses where the taker is a contemporary may be further illustrated by comparing the wills without substitution clauses. In the 12 estates in 1957 where the wife was a legatee, 11 had substitution clauses but in the 7 estates where children were legatees only 3 had substitution clauses. The substituted takers provided for in the wills with substitution clauses further illustrate that the function of a will is to deviate from statute. The common law provided that if a devisee or legatee predeceased the testator the gift lapsed and relatives of the named legatee took nothing. Mllinois has a statute which provides that if the devisee or legatee is a descendant of the testator then the descendants of the primary taker take the estate so devised or bequeathed to the descendant who predeceased the testator. 57 Thus, if there were no substitution clauses, gifts to brothers and sisters or to wives would lapse if the taker predeceased the testator, but gifts to children or to grandchildren would not lapse. In 1957, of the 11 cases where the primary taker was a spouse, in 5 cases the will provided that the substitute takers would be the same persons who would have taken on intestate distribution, and in 6 cases the will deviated from the intestate succession laws. In the 3 situations in 1957 where there was a substitution clause for a gift to children, one of the wills restated the statute, that is, provided that the issue of the deceased child would take. Two of the wills, however, deviated from the statutory substitution and both of them included the deceased child's spouse as a substitute taker. In the 6 wills in which the primary gift was to a brother or sister, 2 provided that the substitutes should be descendants of the deceased taker, 3 included the spouse of the deceased taker and 1 provided that the whole should go to the surviving brothers and sisters. In the 5 situations where the substitution clause was used for a primary taker more distant than brothers and sisters, 3 provided that the property should go to the surviving legatees, 1 to the wife of the deceased legatee and 1 to a named substitute. The 1953 substitution clauses followed the statutory scheme more often than those did in 1957. In the 9 cases where the legatee was a spouse and there was a substitution clause, 7 , or 77 per cent, provided that the substitute takers should be the children of the testator who would be the takers on intestate distribution of the property. In the 8 cases where children were the primary legatees the substitute takers would be the statutory substitutes, that is, the descendants of the deceased primary taker, in 5 , or 62.5 per cent, of the

57 Ill. REV. STAT. ch. 3, § 200 (1961). 
cases. In 25 per cent of the cases there was a deviation from the statutory scheme in order to include a spouse of a deceased taker as a substitute. In 1 , or 12.5 per cent, of the cases where there were children as legatees did the substitution clause provide that the surviving children should take the share of the deceased child. In 1953 where brothers and sisters were primary takers, two-thirds of the substitute takers were to be descendants of brothers and sisters, and one-third were to be the surviving brothers and sisters. In 1 case where the primary takers were grandchildren the substitute taker was a charity, although the testator had relatives as close if not closer than the grandchildren who were the primary takers. Of the 7 cases where the substitution clause was used for primary takers more distant than brothers and sisters, the substitute was named in 2 cases, the gift went to the children of the primary taker or the heirs of the primary taker in 2 cases, to the surviving members of the group of legatees in 1 case and to the residuary estate of the deceased in 2 cases.

The most striking fact in this analysis of the substitution clause-aside from its selective use where the primary taker is a contemporary of the testatoris the introduction through the substitution clause of the spouse of the primary taker as the substitute, a person who would not take under a statutory scheme in case the primary taker predeceased the testator.

\section{F. Other Standard Clauses}

Usually the substitution clause simply provided for the possibility of the taker predeceasing the testator. Only 5 wills in the sample required a primary taker to survive 30 days and a similar number had a common casualty clause.

Clauses attempting to forestall will contests were also not prevalent in the wills under examination. There were none in the 1953 sample and in the 1957 sample of 40 wills there were only 3 such "no contest" clauses.

Another common provision inserted in wills is a series of clauses giving the executor a power of sale which may or may not exist absent the clause in the will. Of the 98 wills in the sample, 40 provided for this kind of administrative power in the executor. ${ }^{58}$ In the 47 estates with real estate, 45 per cent gave the executor the power of sale, whereas in the 51 estates without real estate, 37 per cent gave the executor this power. This would indicate selective use of the power of sale since undoubtedly the executor has a power of sale where there is personal property but probably needs to have authority from the will to sell real estate. In the 58 estates without a power of sale, 47 per cent had real estate and in the 40 estates with power of sale, 50 per cent had real estate.

In the 98 testate estates studied there was only 1 "legal" life estate. In all of the other cases the life estate was equitable under a trust.

In the two years in question there were 24 instances of specific legacies. Two

${ }^{58}$ In The Wisconsin Study at 420, the executor was given detailed powers of some sort in $41 \%$ of all testamentary estates. 
of the specific legacies involved stock, all other cases involved personal effects or specifically described life insurance proceeds.

This analysis of trusts, substitution clauses, common casualty clauses and administrative provisions would seem to indicate that these provisions are not standard boilerplate inserted into a will by a lawyer but are used selectively to fit the situation at hand.

\section{G. Changed Circumstances}

An analysis of the wills in the two years under study revealed three types of changes in circumstances between the execution of the will and the death of the testator: First, there were 4 cases of the death of a legatee prior to the testator's; second, there were 5 cases of an executor who did not serve; and third, there was 1 case of a specific legacy where at the time of death the property was not owned by the deceased.

In the cases where the legatee predeceased the testator, 3 of the 4 cases occurred where the will provided for a substitute taker. In 1 of the cases the named legatee was a brother for whom a substitute taker was not provided either by will or by statute; nevertheless the descendants of the deceased legatee shared in the distribution through a settlement of a "will contest." Since the named legatee was also named as an executor the alleged will contest concerned a method of selection of the substitute executor and the agreement in this proceeding permitted the descendants of the deceased legateeexecutor to take.

In the 5 cases in which the executor did not serve, 2 of the named executors predeceased the testator and 2 were non-residents who were not qualified to serve. In each of these 4 cases the will itself provided for a substitute executor. In 1 case the executor refused to serve.

\section{CONCLUSION}

Several tentative conclusions may be drawn from the survey of estates in Cook County:

1. The bulk of the wealth that passes through the probate court is distributed pursuant to a will even though almost 50 per cent of the estates are intestate.

2. Further study is necessary to determine whether the 85 per cent of adults who have no probated estate have some other means of passing property from one generation to the next or have in fact no accumulated wealth.

3. The intestate succession law concerning the share of the surviving spouse seems to be seriously contrary to the average expectations of the community.

4. The estate administration process is as speedy as the statutory 9 month period for creditor claims permits. 